\title{
On the crystallization conditions of the Neoproterozoic, high-K calc-alkaline, Bragança Paulista-type magmatism, southern Brasília Orogen, SE Brazil
}

\author{
Andrés Fabián Salazar-Naranjo ${ }^{1 *}\left(\mathbb{D}\right.$, Silvio Roberto Farias Vlach ${ }^{1}$
}

\begin{abstract}
Syn-orogenic Neoproterozoic granitic magmatism (ca. 630-600 Ma) in southern Brasilia Orogen includes large batholiths of compositionally expanded high-K calc-alkaline granites (lato sensu) and small occurrences constituted by anatetic leuco-granites associated to the regional metamorphism. We present petrographic, mineralogical and geochemical data for a representative sample of the Bragança Paulista-type granite and estimates for magmatic crystallization conditions. The sample corresponds to a porphyritic hornblende-biotite monzogranite $(C I \approx 20)$ comprising perthitic microcline megacrysts within a medium-grained matrix with plagioclase ( $\left.A n_{30} A b_{70}\right)$, quartz, microcline and mafic minerals. The main mafic minerals are biotite $(0.51 \leq m g \# \leq 0.57)$ and Ca-amphibole (potassic-magnesio-hastingsite, $0.47 \leq m g \# \leq 0.52$ ), with similar volumes; accessory phases (ca. 2 vol.\%) are Fe-Ti oxides (ferrian ilmenite, titanohematite, hematite and magnetite), allanite, apatite, zircon, titanite and sulphides. Our results indicate crystallization at $510 \pm 60 \mathrm{MPa}$ and temperatures from ca. $970^{\circ} \mathrm{C}$ (close-to-liquidus) to $755 \pm 45^{\circ} \mathrm{C}$ (close-to-solidus), under oxidizing conditions, compatible with $0 \leq \Delta N N O \leq+1$. Estimated water and halogen fugacity ratios are $f_{H 2 O} / f_{H F} \geq 10^{5.8}, 10^{3.5} \leq f_{H 2 O} / f_{H C l} \leq 10^{3.8}$ and $f_{H F} / f_{H C l} \leq 10^{2.2}$. The obtained pressure, integrated with available regional geobarometric data, suggests a relative uplift rate about $0.2-0.3(\mathrm{~km} / \mathrm{Ma})$ from the main regional metamorphism to the post-orogenic magmatism in the area.
\end{abstract}

KEYWORDS: Intensive crystallization parameters; high-K calc-alkaline granites; Bragança Paulista-type granites, Neoproterozoic magmatism, Socorro-Guaxupé Nappe.

\section{INTRODUCTION}

Neoproterozoic granite magmatism was widespread in Socorro-Guaxupé Nappe System in Eastern São Paulo state and neighboring areas (e.g., Campos Neto et al. 1984, Wernick et al. 1984, Artur et al. 1991, 1993, Haddad 1995, Campos Neto \& Caby 1999, Janasi et al. 2009, Vinagre et al. 2014). The most voluminous occurrences are made up of, compositionally expanded, high-K calc-alkaline syn-orogenic granites (lato sensu), which build the Socorro and Ipuiúna batholiths (e.g., Campos Neto et al. 1984, Wernick et al. 1984, Haddad 1995, Haddad et al. 1997). Several efforts were made in the last decades to increase our geologic, geochronological and geochemical knowledge on such magmatism as basic clues to understand the regional geodynamic environment in Southeastern Brazil (Artur et al. 1993, Hackspacher et al. 2003, Vinagre et al. 2014). However, none quantitative, or even qualitative, information on mineral chemistry and crystallization conditions for such granite rocks is available up to now.

As a part of a beginning work with experimental petrology and geochemistry using natural granites as starting samples conducted by us, we characterized in detail the petrography, geochemistry and mineralogy of a typical sample from the Bragança Paulista-type granite in the so-called Socorro Batholith, which allows put some constraints on the main intensive crystallization parameters (pressure, temperature and volatile activities) of the associated magmas. This contribution presents results and discusses them in the light of

${ }^{1}$ Departamento de Mineralogia e Geotectônica, Instituto de Geociências, Universidade de São Paulo - São Paulo, (SP), Brazil. E-mails: andres.salazar@usp.br; srfvlach@usp.br

*Corresponding author.

Manuscript ID: 20180033. Received on: 03/23/2018. Approved on: 08/01/2018. 
the current ideas on the evolution of the granite magmatism in the area during the Neoproterozoic. Given the representativeness of the selected sample, the presented inferences may be partial or total extended to the overall Bragança Paulista magmatism with the caution due to inherent limitations of the employed methods and reduced sampling.

\section{GEOLOGICAL SETTING}

The southern Brasília Orogen records the Ediacaran convergence of the São Francisco and Paranapanema cratons, acting as passive and active margins respectively (e.g., Campos Neto \& Caby 1999). These margins were grouped into three main nappe terranes (Fig. 1), as follows:

the Carrancas Nappe System, made up mainly by quartzite and graphite-bearing metapelites, which represents a deformed sedimentary pile with passive margin affinity, metamorphosed under greenschist to lower amphibolite

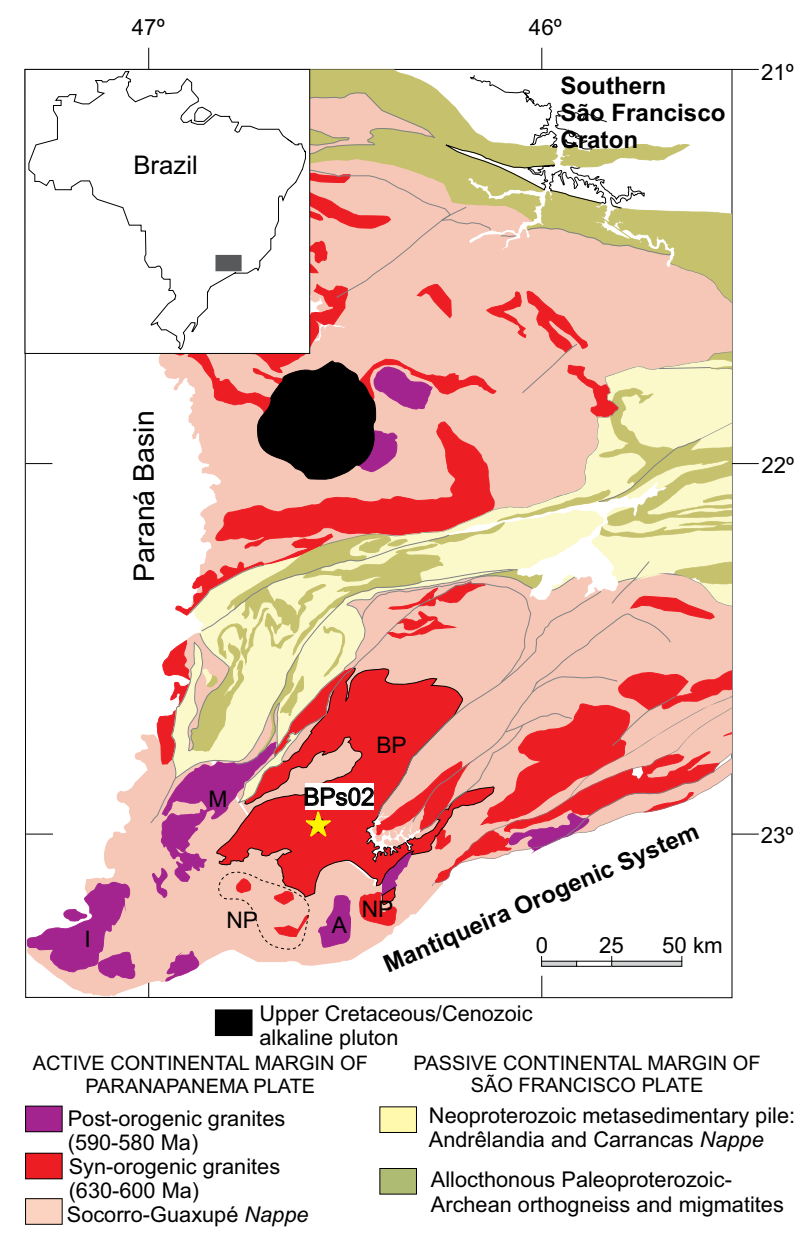

BP: Bragança Paulista; NP: Nazaré Paulista; M: Morungaba; I: Itu; A: Atibaia. Figure 1. Geological map of Socorro-Guaxupé Nappe System area, highlighting the main syn- and post-orogenic granitic occurrences. Simplified from Janasi et al. (2009). facies by 590-570 Ma (Trouw et al. 2000, Campos Neto et al. 2004, 2011);

- the Andrelândia Nappe System, constituted by a great variety of ortho- and paragneisses metamorphosed under mid-pressure amphibolite to high-pressure granulite facies by 610-605 Ma, which is currently interpreted as an accretionary prism (Campos Neto et al. 2004, 2007, 2010, 2011);

- the Socorro-Guaxupé Nappe System, made up mostly of paragneisses, migmatites and granulites formed during the main regional metamorphism at ca. 630-600 Ma, which represents an early magmatic arc related to an older active continental margin (Campos Neto \& Caby 1999, Janasi 1999, Del Lama et al. 2000, Janasi et al. 2005, Martins et al. 2009, Campos Neto et al. 2011, Salazar Mora et al. 2014, Rocha et al. 2017). In this nappe terrane, the estimated conditions of the ultra-high temperature metamorphism peak were ca. $1,170 \mathrm{MPa}$ and $1,030^{\circ} \mathrm{C}$, with a post-peak cooling at ca. $750 \mathrm{MPa}$ and $865^{\circ} \mathrm{C}$ (Martins et al. 2009, Rocha et al. 2017).

An extensive Neoproterozoic granite magmatism (ca. 2,200 $\mathrm{km}^{2}$ ) was emplaced in the Socorro-Guaxupé Nappe System, in part controlled by expressive NE-SW shear zones (Campos Neto \& Caby 1999, Campos Neto et al. 1984, Janasi et al. 2009). It is divided into two main associations (Fig. 1): a syn- orogenic magmatism (ca. 630-600 $\mathrm{Ma}$ ), represented by the Bragança Paulista-type (Socorro I) and Nazaré Paulista-type granites, and a post- orogenic magmatism (ca. 590-570 Ma), represented by the occurrences from the Itu Granite Province.

The Bragança Paulista-type granites comprise a high-K expanded calc-alkaline association (I-type in the sense of Pitcher 1982), made up by metaluminous (to slightly peraluminous) porphyritic tonalite, granodiorite and dominant granites (Campos Neto et al. 1984, Wernick et al. 1984). Previous geochronological data points to emplacement ages of ca. 630-610 Ma (zircon U-Pb), under arguably mid-crustal conditions (Artur et al. 1991, 1993, Ebert et al. 1996, Töpfner 1996). However, recent Sensitive High-Resolution Ion Micro Probe (SHRIMP) II U-Pb dating over zircon crystals from the sample herein studied gave a younger concordia age of $c a$. $605 \mathrm{Ma}$ (V.A. Janasi, personal communication).

The Nazaré Paulista-type granites are composed of peraluminous garnet-, biotite- ( \pm sillimanite, \pm andalusite \pm muscovite) bearing S-type leucogranites, associated with migmatites developed over metasedimentary gneissic rocks. Field relationships suggest magma generation by decompression melting (Artur et al. 1991, Janasi 1999, Janasi et al. 2005, Martins 2006, Martins et al. 2009). 
The Itu Granite Province is made up of post-orogenic sub-alkaline A-type and evolved high-K calc-alkaline metaluminous to slightly peraluminous biotite ( \pm hornblende) granites (Vlach et al. 1990, Janasi et al. 2009) emplaced under relatively shallow crustal levels. The most typical representatives in the area are the Itu Batholith (Pascholati et al. 1987, Galembeck 1997, Galembeck et al. 1997) and most of the so-called Morungaba granites (Vlach 1993).

\section{SAMPLING AND ANALYTICAL METHODS}

Several Bragança Paulista granite outcrops were examined in detail and scrutinized in order to find a relatively fresh representative sample and avoid common hydrothermal alteration inputs (usually detected by dark red-colored alkali-feldspars megacrysts) due to solid-state deformations associated with late transcurrent moves along shear zones. The selected sample (BPs02) was collected in the type-area of the magmatism, along the SP-095 highway, which connects the Bragança Paulista and Amparo cities (Fig. 1). It is relatively homogenous, with a slightly oriented planar structure, and corresponds to a leucocratic, porphyritic, amphibole-biotite granite with centimetric-sized alkali-feldspar megacrysts in a medium-grained matrix constituted mainly by plagioclase, quartz and mafic minerals. Titanite and magnetite may eventually be detected in hand samples. In the selected outcrop, the granite shows incipient to strong planar flow structures with local superposition of more or less concordant solid-state deformation. Schlieren structures made up of mafic minerals and some plagioclase, as well as mafic microgranular enclaves with dioritic compositions, are common outcrop features (Fig. 2).

The laboratory work was done at the GeoAnalitica core facility (University of São Paulo), except for whole-rock trace element analysis, performed at the Isotope Geology Laboratory (State University of Campinas). Petrographic analysis was done under transmitted and reflected light on polished thin sections using Zeiss Axioplan and Axio Imager optical microscopes. Modal proportions were obtained by point-counting, integrating alkali-feldspar, plagioclase, quartz and total mafic mineral counts on rock slices with mafic minerals counts in thin sections (e.g., Vlach 1993), by totalizing 1,000 points computed on $5.0 \mathrm{~cm}$ and $0.1 \mathrm{~mm}$ spaced grids, respectively. Weigh mineral proportions were also quantified by the Rietveld method applied to X-ray whole rock powder patterns, obtained with the D8 Advanced Davinci equipment from Bruker (details in Salazar-Naranjo 2016).

Whole-rock chemical compositions were determined by X-ray fluorescence (XRF) with the PANalytical Axios MAX Advanced equipment, following the procedures described by Mori et al. (1999), while trace elements were quantified through inductively coupled plasma mass spectrometry (ICP-MS) with the X series II (Thermo) equipment, with Collision Cell Technology (CCT), according procedures given in Navarro et al. (2008).

Back-scattered electronic (BSE) imaging and spot quantitative analysis were carried out with the JEOL-8530 field emission electron probe microanalyser (FE-EPMA), provided with five wavelength dispersive (WDS) and one energy dispersive spectrometers (EDS). Quantitative WDS
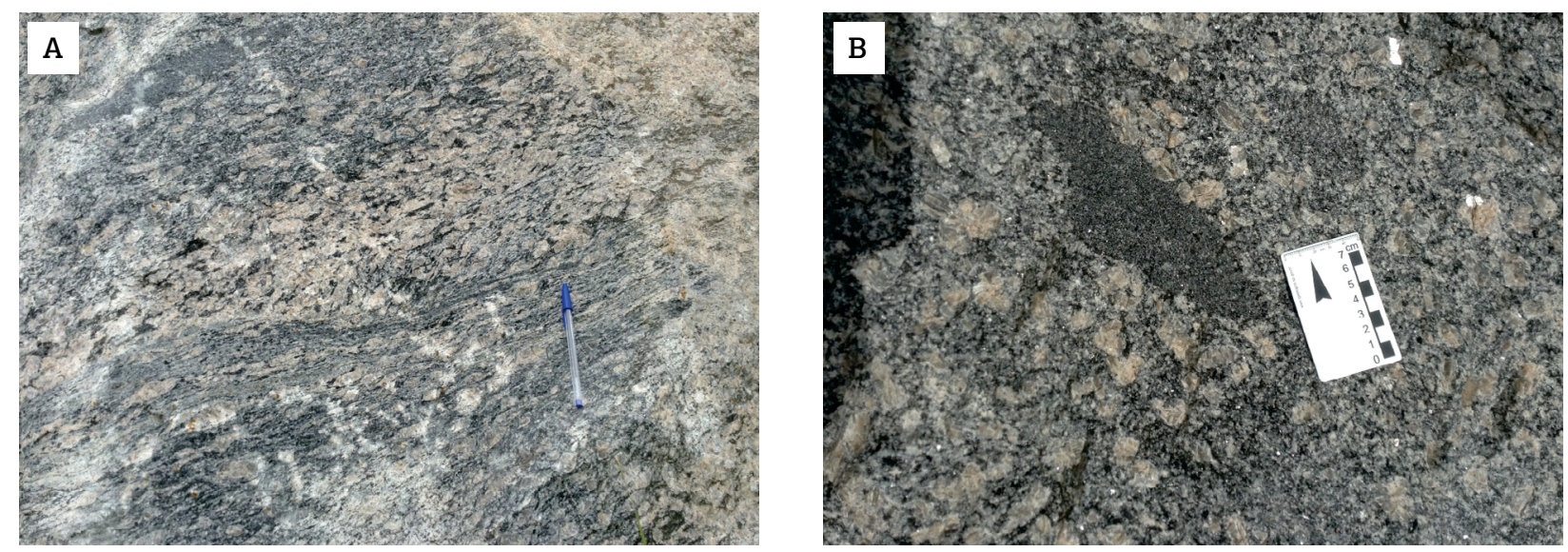

Figure 2. Some representative structural features of the Bragança Paulista-type granite, as observed in the BPs02 studied outcrop. (A) Magmatic flow structures, superimposed by solid-state deformation, evidenced by the arrangement of the mafic minerals and a bit stretched pink alkali-feldspar megacrysts, in a heterogeneous zone of the outcrop. (B) Mafic microgranular enclaves of dioritic composition, and irregular mafic schlieren zones, with pinkish megacrysts of alkali-feldspar slightly oriented. 
spot analyses of the main rock-forming minerals and Fe-Ti oxides were performed with conventional analytical routines (e.g., Gualda \& Vlach 2007), with 15 kV, $20 \mathrm{nA}$ and $5 \mu \mathrm{m}$ for the column accelerating voltage and beam current and diameter, respectively. $\mathrm{F}$ and $\mathrm{Cl}$ analyses $(\mathrm{K} \alpha$ spectral lines) in biotite and amphibole were carried out with large area $\operatorname{TAP}(\mathrm{H})$ and conventional PET(J) analyzer crystals using fluorapatite and sodalite as standards, respectively; halogen detection limits were about $55 \mathrm{ppm}$ in both cases. In the case of the Fe-Ti oxides, due to the thin exsolution lamellae observed in BSE images, the analytical work was done with $12 \mathrm{kV}, 10 \mathrm{nA}$ and $2 \mu \mathrm{m}$, respectively, for spatial resolution improvement. Natural and synthetic standards from the Smithsonian Institution and the Geller ${ }^{\mathrm{TM}}$ (McGuire et al. 1992) collections were used for the analytical setup. Raw data reduction and matrix effect corrections were computed with the PRZ/ Armstrong software from JEOL.

Cationic proportions and mineral formulae were obtained with the MINCAL software (e.g., Gualda \& Vlach 2005). In the case of amphiboles, the $\mathrm{Fe}^{3+}$ maximum criterion based on the Schumacher method (Leake et al. 1997) was assumed, following the suggestions proposed by Gualda $\&$ Vlach (2005). Fe-Ti oxides mineral formulae were computed following Carmichael \& Nicholls (1967).

\section{RESULTS}

\section{General petrography and whole-rock geochemistry}

The main petrographical and litogeochemical features of the studied sample are presented in brief in the following as a background for the next sections.

\section{Petrography}

The studied granite has a porphyritic texture given by grayish to slightly pink tabular alkali feldspar megacrysts (23 vol.\%), up to $3 \mathrm{~cm}$ long, in a medium-grained matrix (77 vol.\%) made up of plagioclase, quartz, minor alkali-feldspar, amphibole and biotite. The accessory minerals include $\mathrm{Fe}-\mathrm{Ti}$ oxides (ilmenite, magnetite and hematite), titanite, allanite, apatite, zircon and some sulphides. Modal data (Tab. 1) allows to classify the sample as amphibole-biotite monzogranite, with $\mathrm{M}$ (total mafic) $\approx 22$ vol. $\%$ and $\mathrm{Q}$ (quartz) $\approx 21$ vol.\%, according to the International Union of Geological Sciences (IUGS) nomenclature (Le Maitre et al. 2002).

The megacryst alkali-feldspar is made up of sub-idiomorphic crystals and corresponds to a microcline, with well-developed chessboard twining and variable quantities of exsolved albite (Fig. 3A). Apatite and quartz are common inclusions. In the matrix, microcline (averaging ca.

Table 1. Modal (point-counting, volume, and X-ray powder diffratometry - XRD, mass, estimates) and whole-rock geochemical composition of the $\mathrm{BPs02}$ sample from the Bragança Paulista-type granite.

\begin{tabular}{|c|c|c|c|c|c|c|c|c|c|c|}
\hline \multirow{3}{*}{$\begin{array}{l}\text { Mineral } \\
\text { Plagioclase }\end{array}$} & \multicolumn{2}{|c|}{ Modal data } & \multirow{2}{*}{\multicolumn{2}{|c|}{$\begin{array}{l}\text { Major elements } \\
\text { (wt. \%) }\end{array}$}} & \multirow{2}{*}{\multicolumn{6}{|c|}{ Trace elements (ppm) }} \\
\hline & \multirow{2}{*}{$\begin{array}{c}(\text { vol. \%) })^{* *} \\
29.00\end{array}$} & \multirow{2}{*}{$\begin{array}{c}\text { (wt. \%) })^{* * *} \\
26.0\end{array}$} & & & & & & & & \\
\hline & & & $\mathrm{SiO}_{2}$ & 62.89 & $\mathrm{Li}$ & 22.5 & $\mathrm{Nb}$ & 16.12 & $\mathrm{~Tb}$ & 1.06 \\
\hline Quartz & 16.60 & 19.0 & $\mathrm{TiO}_{2}$ & 1.02 & $\mathrm{Be}$ & 3.63 & Mo & 0.96 & Dy & 4.93 \\
\hline K-feldspar* & 32.10 & 29.7 & $\mathrm{Al}_{2} \mathrm{O}_{3}$ & 15.46 & Sc & 8.61 & $\mathrm{Cd}$ & 0.12 & Ho & 0.88 \\
\hline Biotite & 9.76 & 12.6 & $\mathrm{Fe}_{2} \mathrm{O}_{3}{ }^{\mathrm{T}}$ & 5.16 & $\mathrm{~V}$ & 79.0 & Sn & 3.15 & $\mathrm{Er}$ & 2.37 \\
\hline Amphibole & 9.56 & 12.7 & $\mathrm{MnO}$ & 0.09 & $\mathrm{Cr}$ & 68.1 & $\mathrm{Sb}$ & 0.03 & $\mathrm{Tm}$ & 0.29 \\
\hline Magnetite & 0.31 & - & $\mathrm{MgO}$ & 1.96 & Co & 11.22 & Cs & 1.40 & $\mathrm{Yb}$ & 1.96 \\
\hline Ilmenite & 1.32 & - & $\mathrm{CaO}$ & 3.79 & $\mathrm{Ni}$ & 10.29 & $\mathrm{Ba}$ & 1381 & $\mathrm{Lu}$ & 0.27 \\
\hline Sulphide & 0.12 & - & $\mathrm{Na}_{2} \mathrm{O}$ & 3.28 & $\mathrm{Cu}$ & 17.96 & $\mathrm{La}$ & 102 & Hf & 8.44 \\
\hline Titanite & 0.12 & - & $\mathrm{K}_{2} \mathrm{O}$ & 4.24 & $\mathrm{Zn}$ & 87.7 & $\mathrm{Ce}$ & 161 & $\mathrm{Ta}$ & 1.03 \\
\hline Allanite & 0.50 & - & $\mathrm{P}_{2} \mathrm{O}_{5}$ & 0.36 & $\mathrm{Ga}$ & 21.7 & $\operatorname{Pr}$ & 16.75 & $\mathrm{~W}$ & 3.37 \\
\hline Zircon & 0.31 & - & LoI & 0.72 & $\mathrm{Rb}$ & 154 & $\mathrm{Nd}$ & 62.5 & $\mathrm{~Pb}$ & 29.24 \\
\hline Apatite & 0.31 & - & - & - & $\mathrm{Sr}$ & 687 & $\mathrm{Sm}$ & 9.96 & $\mathrm{Bi}$ & 0.07 \\
\hline- & - & - & - & - & $\mathrm{Y}$ & 25.1 & $\mathrm{Eu}$ & 2.26 & Th & 13.85 \\
\hline Total & 100.00 & 100.0 & Total & 98.96 & $\mathrm{Zr}$ & 303 & $\mathrm{Gd}$ & 8.42 & $\mathrm{U}$ & 1.10 \\
\hline
\end{tabular}

*Alkali-felspar megacryts $\left(23\right.$ vol.\%) and matrix (9 vol.\%); **integrate point-counting between in rock slices and thin sections; ${ }^{* * *}$ estimated with XRD. 
9 vol.\% and size about $0.2 \mathrm{~mm}$ ) is made up of predominant interstitial and xenomorphic clean crystals; exsolved albite is relatively rare (Fig. 3B). Plagioclase $(<2.2 \mathrm{~mm})$ is the main felsic mineral in the groundmass. It appears as prismatic/tabular idiomorphic and sub-idiomorphic crystals showing albite or, to a lesser extent, combined albite-carlsbad twinning (Fig. 3C); slight bending of the lamellar twinning evidences some plastic deformation. The observed crystal sections are optically homogeneous; minor compositionally zoning is evidence solely by some increase
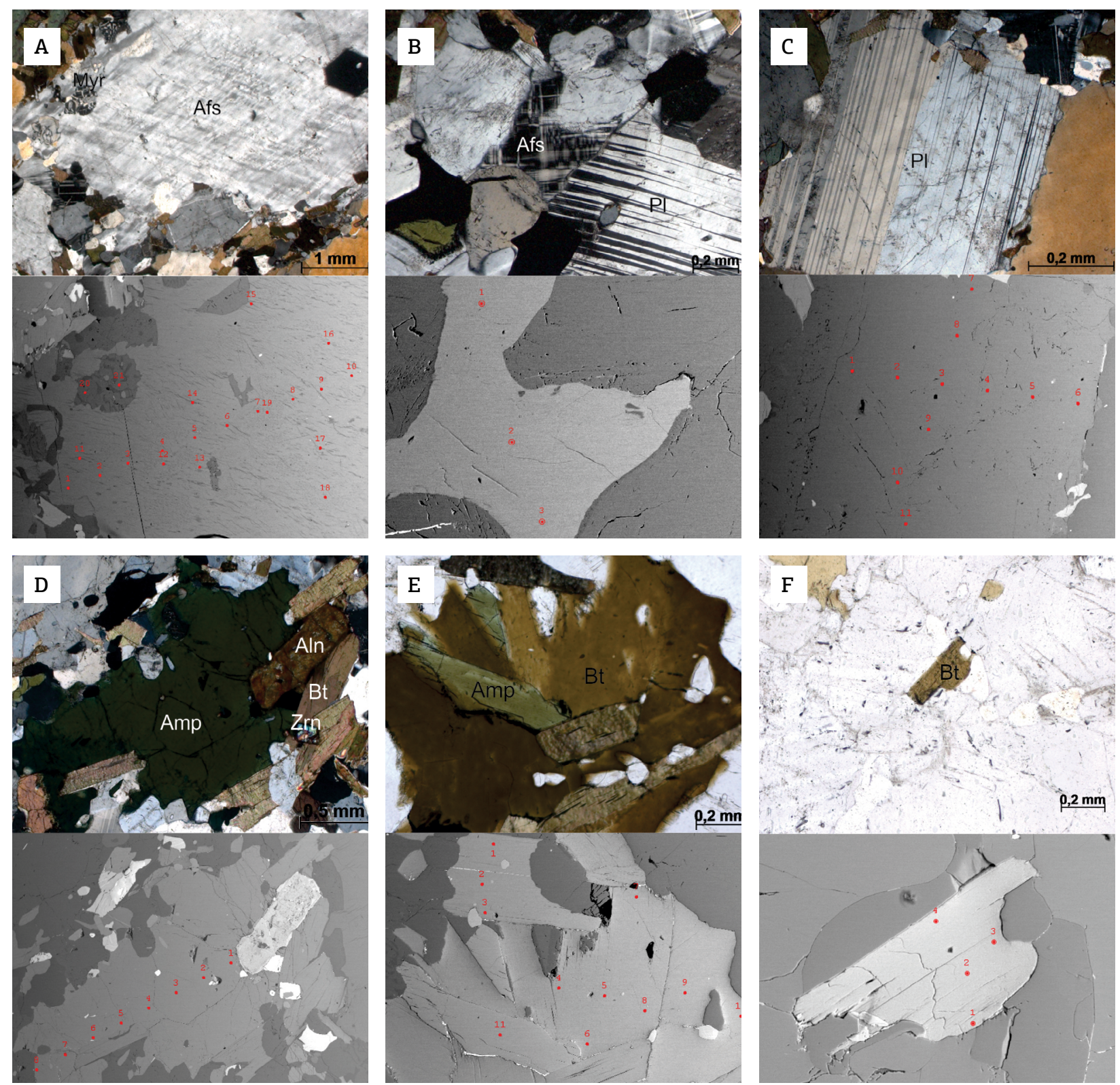

Afs: alkali-feldspar; Myr: myrmekite; Pl: plagioclase; Amp: amphibole; Bt: biotite; Aln: allanite; Zrn: zircon.

Figure 3. Optical cross-polarized transmitted light (top) and back-scattered electronic (BSE) (bottom) images emphasizing some textural features of the felsic and mafic minerals in the studied sample. (A) Perthitic alkali feldspar megacryst with crosshatched twin; note myrmekite on the left. (B) Exsolution-free, crosshatched twinned, intersticial alkali feldspar in the rock matrix. (C) Idiomorphic, tabular, non-zoned plagioclase with combined albite-carlsbad twinning in the rock matrix. (D) Subidiomorphic, non-zoned, calcium amphibole (dark green), associated biotite, Fe-Ti oxides, zircon, apatite and zoned allanite, the latter partially included in it. Note straight contacts with biotite. (E) Brown pleochroic biotite aggregates with straight contacts among crystals, with inclusions of quartz and apatite. (F) Fine-grained biotite associated with feldspar and quartz crystals. Note the homogeneous BSE mineral patterns. Red points identify wavelength dispersive spectroscopy (WDS) analytical spot locations. 
of saussurite alteration in crystal cores. Their compositions, estimated through the optical Michel-Lévy method over [010] crystallographic zone's sections of albite-twinned crystals, correspond to a sodic-andesine. Amphibole and biotite inclusions do appear. Myrmekite intergrowths occur associated with alkali feldspar crystals. Quartz $(\leq 2.7 \mathrm{~mm})$ occurs as xenomorphic interstitial crystals usually with undulatory extinction.

Amphibole $(5-13 \mathrm{~mm})$ is idiomorphic to sub-idiomorphic and optically homogeneous, with a pleochroic formula given by $\alpha=$ dark green brownish, $\beta=$ green and $\gamma=$ light yellow and a $\mathrm{Z} \Lambda \mathrm{c}$ extinction angle about $20^{\circ}$, typical of common hornblende (Fig. 3D). The main inclusions are apatite and zircon. Biotite comprises two textural types, the first is made up of well-developed (up to $0.6 \mathrm{~mm}$ ) plate crystals and appears associated with amphibole, sometimes replacing it (Fig. 3E), while the second is constituted by small crystals $(<0.2 \mathrm{~mm})$ closely associated with the felsic minerals (Fig. 3F). The pleochroic schemes are similar in both cases, with $\alpha=$ dark to medium brown, $\beta=$ dark-brown and $\gamma=$ yellow to pale-brown colors.

$\mathrm{Fe}-\mathrm{Ti}$ oxides are the commonest opaque phases and, among them, ilmenite is dominant. It appears as sub-idiomorphic crystals (average size $0.7 \mathrm{~mm}$ ) with thin lamellae exsolution patterns parallel to (0001), constituted by two rhombohedral oxides: titanohematite $(\leq 0.07 \mathrm{~mm})$ and hematite $(\leq 0.03 \mathrm{~mm})$, which are lens- and lath-shaped, respectively (Fig. 4A). Hematite was recognized by its strong bi-reflectance. Magnetite is usually smaller $(\leq 0.5 \mathrm{~mm})$, idiomorphic and exsolution-free under reflected light. Ilmenite crystals associated with magnetite do not exhibit pure hematite exsolution, and the titanohematite exsolution lamellae are more sinuous- and/or droplet-shaped (Fig. 4B); of note, the area directly in contact with magnetite is exsolution-free. Rarely some minute crystals of sulphide (pyrite and chalcopyrite) are observed.

Besides the Fe-Ti oxides, allanite is the main accessory mineral. It forms tabular crystals (up to $1 \mathrm{~mm}$ ), mostly associated with the main mafic silicates (Fig. 3D). It is slightly pleochroic (from light brownish to reddish colors) and shows strong zoning patterns accentuated by late metamictization and related alteration processes. Titanite occurs as rare idiomorphic primary crystals (up to $0.3 \mathrm{~mm}$ ) and very often as thin mantles partially substituting for the opaque phases, especially ilmenite. Apatite $(\leq 0.2 \mathrm{~mm})$ is idiomorphic, clean, and appear mostly as inclusions in the other phases. Zircon $(\leq 0.1 \mathrm{~mm})$ is idiomorphic with well-developed zoning patterns; minute inclusions of apatite and some unrecognized phases are arranged according zircon growth faces.

\section{Whole-rock geochemistry}

Analytical data for the BPs02 sample is presented in Tab. 1. In the following discussion, our results are integrated with the available geochemical data for the Bragança Paulista Batholith (BPB) from Campos Neto et al. (1984), Wernick et al. (1984) and Artur et al. (1993). Of note, the compiled whole-rock analyses are significantly old and evidence some analytical problems or representativeness issues. Overall, they display relatively well the main general geochemical fingerprints, certainly.

The BPB granites geochemical features are akin to the typical expanded high-K calc-alkali to alkali-calcic granites, with $55 \leq \mathrm{SiO}_{2}$ (wt. \%) $\leq 70$. They are high-K $\left(2.5-5.9 \mathrm{~K}_{2} \mathrm{O}\right.$ wt.\%), metaluminous to slightly peraluminous, with 0.82 $\leq$ ASI $\left[=\mathrm{Al}_{2} \mathrm{O}_{3} /\left(\mathrm{CaO}+\mathrm{Na}_{2} \mathrm{O}+\mathrm{K}_{2} \mathrm{O}\right)\right.$, moles $] \leq 1.02$, and magnesian, with $0.51 \leq \mathrm{fe} \#\left[=\mathrm{FeO}^{\mathrm{T}} /\left(\mathrm{FeO}^{\mathrm{T}}+\mathrm{MgO}\right)\right.$, wt. $\%$ oxides $] \leq 0.78$ (Figs. 5A, 5B and 5C, see also Frost et al. 2001, Le Maitre et al. 2002). As typical features, fe\# values are higher than those observed in modern active continental margins batholiths, and $\mathrm{Al}_{2} \mathrm{O}_{3}$ contents decrease as $\mathrm{SiO}_{2}$ increases due mainly to the decreasing biotite and plagioclase modal contents in the evolving magmatic trend (Fig. 5D). Our sample is representative of intermediate compositions.

Trace element patterns are characterized by well-defined negative $\mathrm{Nb}$ and $\mathrm{Ta}$ anomalies in relation to the large-ion lithophile (LIL) and light rare earth (LRE) elements (Fig. 6), a most typical feature of calc-alkaline rocks associated with subduction environments (e.g., Rollinson 1993). The rare-earth elements (REE) define high light rare-earth elements (LREE)/heavy rare-earth elements (HREE) $\left(\mathrm{La}_{\mathrm{N}} / \mathrm{Yb}_{\mathrm{N}} \approx 37\right)$, well-defined LREE $\left(\mathrm{La}_{\mathrm{N}} /\right.$ $\left.\mathrm{Sm}_{\mathrm{N}} \approx 6.5\right)$, moderate HREE $\left(\mathrm{Gd}_{\mathrm{N}} / \mathrm{Yb}_{\mathrm{N}} \approx 3.6\right)$ fractionation patterns, and negative $\mathrm{Eu}$ anomaly $\left(\mathrm{Eu} / \mathrm{Eu}^{*}-0.8\right)$. The patterns observed in the compiled data set are variable to some extent, but high $\mathrm{La}_{\mathrm{N}} / \mathrm{Yb}_{\mathrm{N}}$ ratios and slight negative Eu anomalies are common features to all.

\section{Mineral textures and chemistry}

Representative WDS quantitative compositions of feldspars, amphibole and biotite, and Fe-Ti oxides are shown in Tabs. 2 and 3, respectively. The complete analytical data are available in the Supplementary Tab. A1. Their main characteristics are summarized in the following.

\section{Alkali feldspar}

The host potassic phase of the megacryst alkali-felsdpar compositions lies in the range $\mathrm{Or}_{94.4} \mathrm{Ab}_{5.4} \mathrm{An}_{0.2}-\mathrm{Or}_{85.4}$ $\mathrm{Ab}_{14} \mathrm{An}_{0.6}$, with $\mathrm{Ba}, \mathrm{Sr}$ and $\mathrm{Fe}^{3+}$ contents about $0.045,0.017$ and 0.008 cations per formula unit (cpfu), respectively (Tab. 2, Fig. 7). Albite $\left(\mathrm{Ab}_{96.1} \mathrm{Or}_{3.3} \mathrm{An}_{0.7}-\mathrm{Ab}_{97.3} \mathrm{Or}_{1.0} \mathrm{An}_{1.7}\right)$ appears mainly as string-lets and string-rods exsolution 

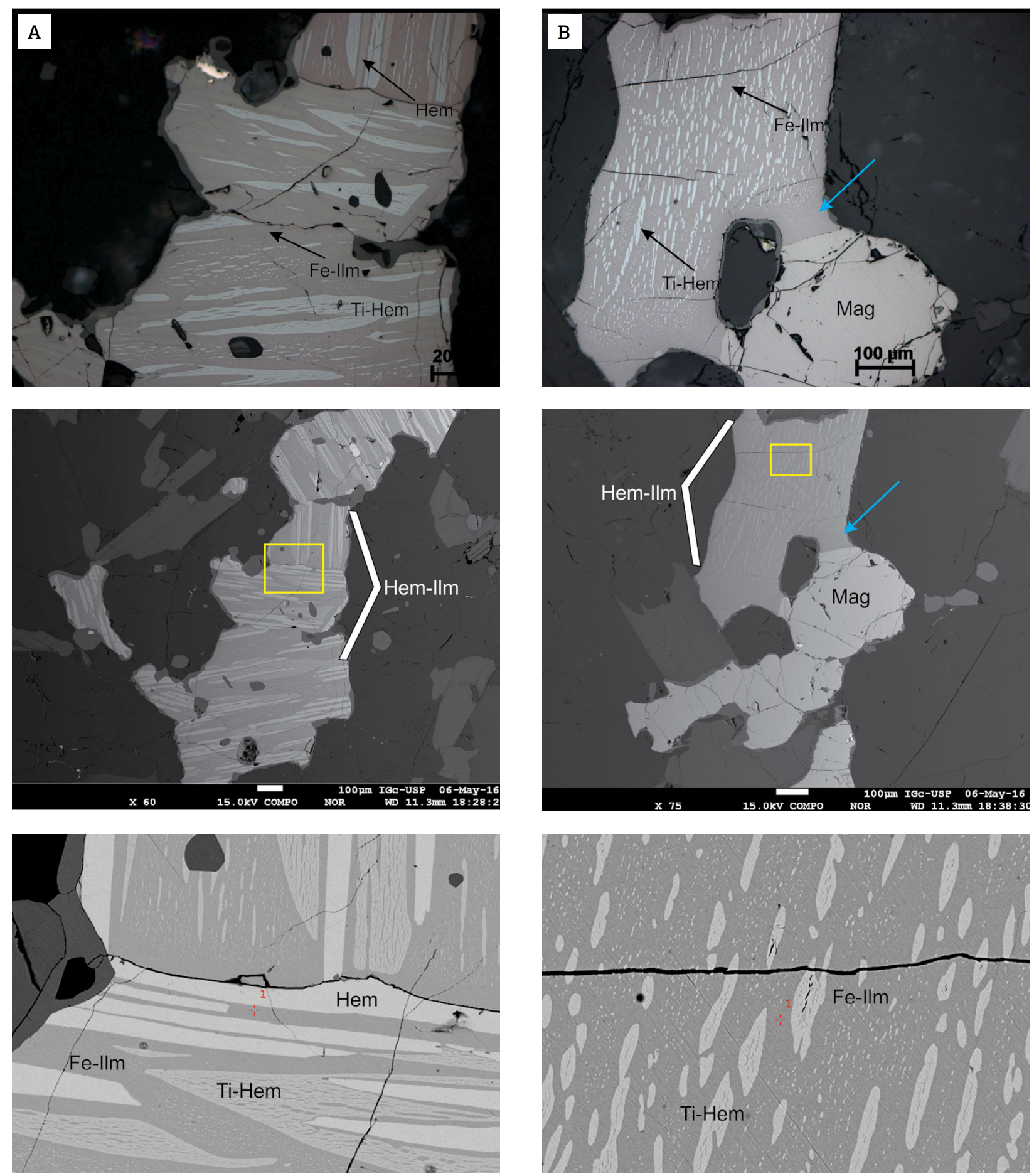

Hem: hematite; Ti-Hem: titanohematite; Mag: magnetite; Fe-Ilm: ferrian ilmenite; Hem-Ilm: hemo-ilmenite.

Figure 4. Optical reflected light (top) and back-scattered electronic (BSE) (center and bottom) images of Fe-Ti oxides in the studied sample. (A) Fe-Ti oxide textural association I: Sub-idiomorphic hemo-ilmenite grain with ferrian ilmenite host (pink-grey and dark-grey, respectively) with oriented straight lamellae of hematite (pink and light-grey, respectively) and titanohematite (white and light-grey, respectively), which, in turn, presents lamellae and drop-like exolution of ilmenite. (B) Fe-Ti oxide association II: subhedral hemo-ilmenite grain with ferrian ilmenite host (pink-grey and dark-grey, respectively) with sinuous titanohematite (white and grey, respectively), associated with subhedral exsolution-free magnetite (light pinkish-grey and light-grey, respectively). Blue arrows indicate ilmenite exsolutions-free portions in contact direct with magnetite. Red points locate wavelength dispersive spectroscopy (WDS) analytical spot locations. Yellow squares identify detailed BSE image areas (bottom). 
A
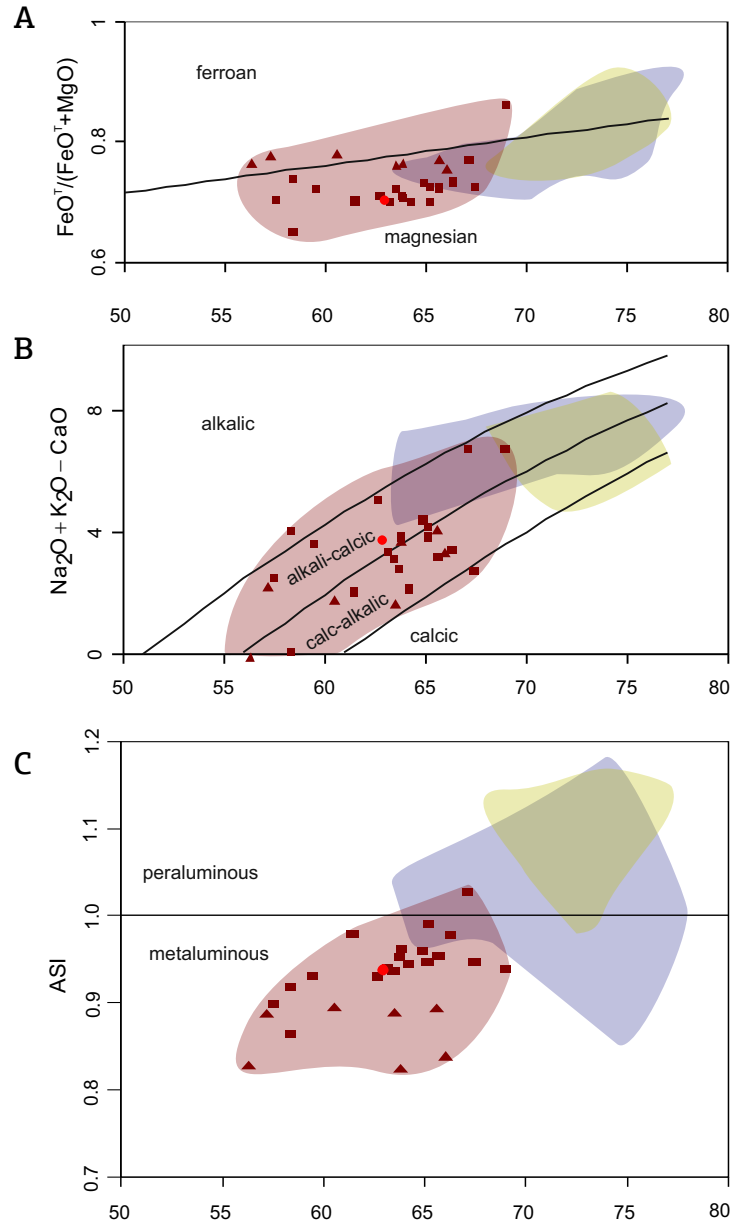

D

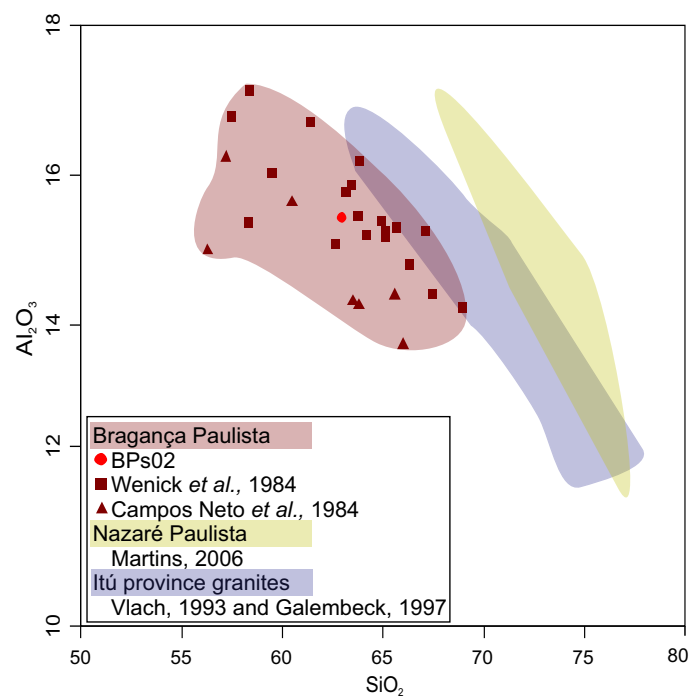

Figure 5. Typical geochemical features of the syn- and post- orogenic granites from the studied area, as depicted in conventional diagrams. (A) $\mathrm{FeO}^{\mathrm{T}} /\left(\mathrm{FeO}^{\mathrm{T}}+\mathrm{MgO}\right)$ vs. $\mathrm{SiO}_{2}$; (B) $\mathrm{Na}_{2} \mathrm{O}+\mathrm{K}_{2} \mathrm{O}-\mathrm{CaO}$ vs. $\mathrm{SiO}_{2}$; (C) alumina saturation index (ASI) vs. $\mathrm{SiO}_{2}$; (D) $\mathrm{Al}_{2} \mathrm{O}_{3}$ vs. $\mathrm{SiO}_{2}$. $\mathrm{A}, \mathrm{B}$ and $\mathrm{C}$ according Frost et al. (2001). Note that the studied BPs2 sample represents intermediate compositions within the compiled Bragança Paulista data. See text for discussion. patterns (Fig. 7). The integrated alkali-feldspar compositions, based on BSE imaging (e.g., Gualda 2001), allow to recognize three groups: $\mathrm{Or}_{76.8} \mathrm{Ab}_{22.9} \mathrm{An}_{0.3}$ (mainly stringlets exsolution patterned crystal zones); $\mathrm{Or}_{85.7} \mathrm{Ab}_{14.1} \mathrm{An}_{0.2}$ (string-lets and string-rods patterns in similar volumes) and $\mathrm{Or}_{93.4} \mathrm{Ab}_{6.5} \mathrm{An}_{0.1}$ (mainly string-rods pattern). The first one, with high $\mathrm{Ab}$ contents, arguably approaches better the expected primary alkali-feldspar compositions.

The matrix, relatively exsolution-poor, alkali-feldspar presents compositions between $\mathrm{Or}_{88.8} \mathrm{Ab}_{10.6} \mathrm{An}_{0.5}$ and $\mathrm{Or}_{92.8} \mathrm{Ab}_{7.1} \mathrm{An}_{0.1}$, somewhat similar to the megacrysts, but shows a slightly great content in the Celsian molecule (Tab. 2).

\section{Plagioclase}

Plagioclase crystals are relatively homogeneous, with very slightly zoning patterns. Their compositions are in the range $\mathrm{Ab}_{65.4} \mathrm{Or}_{2.7} \mathrm{An}_{31.9}-\mathrm{Ab}_{69.8} \mathrm{Or}_{0.8} \mathrm{An}_{29.4}$ (Tab. 2, Fig. 7). Crystal cores are somewhat more calcic and richer in the orthoclase molecule and $\mathrm{Sr}$ and $\mathrm{Fe}^{3+}$ contents as compared with crystal rims. Ba contents are always low (<0.006 cpuf). In the late, post-magmatic, myrmekite intergrowths, compositions are slightly more sodic and, as typical, $\mathrm{Fe}^{3+}$ abundances are lower (ca. $0.015 \mathrm{cpfu}$ ) as compared with the primary crystal rims.

\section{Amphibole}

Amphibole is also texturally and compositionally homogeneous, with $0.87 \leq{ }^{\mathrm{B}} \mathrm{Ca} /{ }^{\mathrm{B}}(\mathrm{Ca}+\mathrm{Na}) \leq 0.92,0.47 \leq \mathrm{mg} \# \leq$ $0.52,1.927 \leq \mathrm{Al}^{\mathrm{T}} \leq 2.219$ (Tab. 2, Fig. 8). Its compositions approaches the typical hastingsite (e.g., Deer et al. 1997). According to Hawthorne et al. (2012), it is classified as a potassic-magnesio-hastingsite; $\mathrm{F}$ and $\mathrm{Cl}$ contents are low, up to 0.02 and $0.20 \mathrm{wt} . \%$, respectively. Considering full-filled A sites in the structural formulae, an average $\mathrm{H}_{2} \mathrm{O}$ content about $1.75 \mathrm{wt} . \%$ is estimated.

The homogeneity of our amphibole compositions does not allow a better evaluation of the main substitution vectors, in common with typical Ca-amphiboles from granitic rocks (e.g., Vyhnal et al. 1991; cf. also Vlach 1993). However, the diagrams depicted in Fig. 8 suggest, at least, that CANT $\left({ }^{\mathrm{M} 4} \mathrm{Ca}+{ }^{\mathrm{VI}} \mathrm{Al}={ }^{\mathrm{M} 4} \mathrm{Na}+\mathrm{Ti}\right)$ and hastingsite-pargasite $\left({ }^{\mathrm{A}} \square+\right.$ $\left.2 \mathrm{Si}+\mathrm{Mg}={ }^{\mathrm{A}} \mathrm{Na}+2^{\mathrm{IV}} \mathrm{Al}+\left(\mathrm{Fe}^{3+},{ }^{\mathrm{VI}} \mathrm{Al}\right)\right)$ type coupled substitutions were predominant over the $\mathrm{Al} / \mathrm{Fe}$ tschermakite (2Si $\left.+2 \mathrm{Mg}=2^{\mathrm{IV}} \mathrm{Al}+2\left(\mathrm{Fe}^{3+},{ }^{\mathrm{VI}} \mathrm{Al}\right)\right)$ and edenite $\left({ }^{\mathrm{A}} \square+\mathrm{Si}={ }^{\mathrm{A}} \mathrm{Na}+\right.$ $\left.{ }^{\mathrm{IV}} \mathrm{Al}\right)$ type substitutions.

\section{Biotite}

Annite and phlogopite end-members are largely predominant in our biotite compositions $\left(\mathrm{Ann}_{43} \mathrm{Phl}_{57}-\mathrm{Ann}_{48} \mathrm{Phl}_{52}\right.$, Fig. 9A); siderophyllite and eastonite molecules contents are very low ( $\left.{ }^{\mathrm{VI}} \mathrm{Al}<0.16 \mathrm{cpfu}\right)$. Such compositions are common 
among typical biotites from orogenic calc-alkaline suites, as compared with the data presented by Abdel-Rahman (1994) and Nachit et al. (2005).

As described for plagioclase and amphibole, biotite is chemical homogeneous. Some variations in Ti contents may be explained by a $\mathrm{Ti}+{ }^{\mathrm{IV}} \mathrm{Al}={ }^{\mathrm{VI}} \mathrm{Al}+\mathrm{Si}$ type exchange vector (Fig. 9B). Of note, titanium contents in biotite are negatively correlated with mg\# (Fig. 9C), and biotite crystals associated with amphibole presents relatively low Ti contents as compared with the crystals associated with felsic minerals.

An interesting aspect emerging from our biotite compositions is that they evidence a $\mathrm{Mg}-\mathrm{Cl}$ but not a Fe-F avoidance pattern (Munoz 1984, Mason 1992, Icenhower \& London 1997), which contrasts with the observed patterns in most among the late- to post-orogenic regional granites (e.g., Vlach 1993, Vlach \& Ulbrich 1994). This feature could be attributed to biotite and amphibole simultaneous crystallization during most of the melt crystallization range (e.g., Teiber et al. 2014).

\section{Fe-Ti oxides}

Fe-Ti oxides are represented by ferrian ilmenite, titanohematite, magnetite and hematite. Reflected-light petrography and BSE images suggest two textural associations among these minerals, as detailed below, according the terminology of Balsley \& Buddington (1958).

Association I is made up of sub-idiomorphic hemoilmenite grains (Tab. 3, Fig. 4A and 10), constituted by ferrian ilmenite host $\left(\mathrm{Ilm}_{88-90} \mathrm{Hem}_{5-8} \mathrm{Pph}_{2-3} \mathrm{Gk}_{1-2}\right)$ with more or less oriented exsolution lamellae of hematite $\left(\mathrm{Hem}_{\approx 100}\right.$, with $\mathrm{FeO} \leq 1.3$ and $\mathrm{TiO}_{2} \leq 1.6$ wt.\%) and titanohematite $\left(\mathrm{Ilm}_{14-20} \mathrm{Hem}_{80-86} \mathrm{Pph}_{0} \mathrm{Gk}_{0}\right)$, which, by its turn, presents lamellae and drop-like ferrian ilmenite exsolution $\left(\mathrm{Ilm}_{67-87} \mathrm{Hem}_{9-31} \mathrm{Pph}_{2-3} \mathrm{Gk}_{0-2}\right)$.
Association II (Table 3, Figs. 4B and 10) is composed of pure magnetite grains $\left(\mathrm{Hc}_{1} \mathrm{Mag}_{99} \mathrm{Usp}_{0} \mathrm{Spl}_{0}\right)$ associated with hemo-ilmenite grains, which are made up of ferrian ilmenite host $\left(\mathrm{Ilm}_{78-86} \mathrm{Hem}_{4-12} \mathrm{Pph}_{7-8} \mathrm{Gk}_{1-2}\right)$, containing exsolved lamellae and very fine drop-like exsolutions (up to ca. $2 \mu \mathrm{m})$ of titanohematite $\left(\mathrm{Ilm}_{16-18} \mathrm{Hem}_{82-84} \mathrm{Pph}_{0-1} \mathrm{Gk}_{0}\right)$, which contains exsolved ferrian ilmenite $\left(\mathrm{Ilm}_{80} \mathrm{Hem}_{11} \mathrm{Pph}_{8} \mathrm{Gk}_{2}\right)$.

The primary hemo-ilmenite compositions were recalled using the available chemical quantitative spot analysis, the relative volumes, estimates from representative BSE images, and average densities, given by Deer et al. (2011), for the exsolved and host oxide phases. The integrated composition of hemo-ilmenite from Association II ( $\mathrm{Ilm}_{69} \mathrm{Hem}_{23} \mathrm{Pph}_{7} \mathrm{Gk}_{1}$ ) presents higher ilmenite and pyrophanite contents as compared with that constituting Association I ( $\left.\operatorname{Ilm}_{53} \mathrm{Hem}_{45} \mathrm{Pph}_{1} \mathrm{Gk}_{1}\right)$ (see also Fig. 10).

\section{CRYSTALLIZATION CONDITIONS}

\section{Amphibole-plagioclase thermobarometry and Al-in-hornblende barometry}

Various experimental- and/or empirical-based calibrations proposal by Blundy \& Holland (1990), Holland \& Blundy (1994) and Molina et al. (2015), based on the equilibrium between plagioclase and $\mathrm{Ca}$-amphibole, were examined and applied to our chemical data. P-T result ranges are compared in Fig. 11A. The models of Holland \& Blundy (1994, $\mathrm{T}_{\mathrm{B}}$ Model) and Molina et al. (2015), converge well to temperatures and pressures around 756 $( \pm 45)^{\circ} \mathrm{C}$ and $510( \pm 60) \mathrm{MPa}$. Thus, they are considered our near-solidus temperatures and emplacement pressures preferred values. Of note, given the relatively homogeneity of our chemical compositions, there are not significant

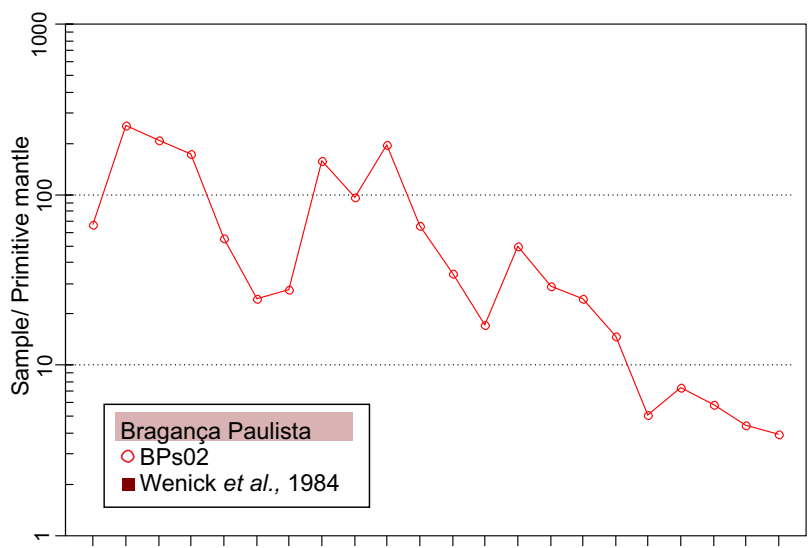

Cs Rb Ba Th U Nb Ta La Ce Pb Pr Sr P Nd Zr SmEu Ti Dy Y Yb Lu

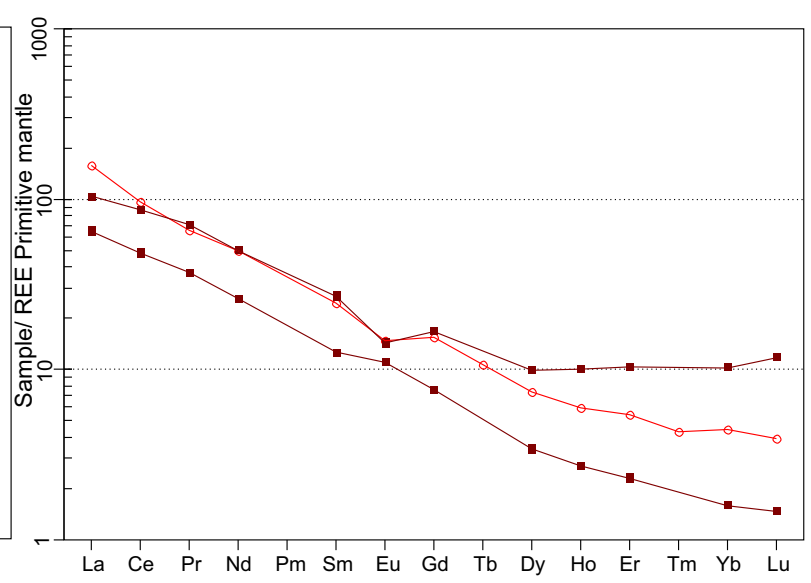

Figure 6. Normalized multielement diagram, according McDonough \& Sun (1995), for the studied BPs02 sample, and rare-earth elements (REE) patterns, for the studied and two other available samples from the compiled data set. See text for discussion. 
Table 2. Representative wavelengths dispersive spectroscopy (WDS) spot analyses (wt.\%) and structural formulae for feldspars, amphibole and biotite in the $\mathrm{BBs02}$ sample from the Bragança Paulista-type granite.

\begin{tabular}{|c|c|c|c|c|c|c|c|c|c|c|}
\hline \multirow[b]{3}{*}{ Point ID } & \multicolumn{3}{|c|}{ Alkali Feldspar } & \multicolumn{3}{|c|}{ Plagioclase } & \multirow{2}{*}{\multicolumn{2}{|c|}{ Amphibole }} & \multirow{2}{*}{\multicolumn{2}{|c|}{ Biotite }} \\
\hline & \multirow{2}{*}{$\begin{array}{c}\text { Host } \\
18.8\end{array}$} & \multirow{2}{*}{$\begin{array}{c}\text { Interstitial } \\
21.3\end{array}$} & \multirow{2}{*}{$\begin{array}{c}\text { Ab exsolution } \\
24.10\end{array}$} & \multirow{2}{*}{$\begin{array}{l}\text { Core } \\
22.3\end{array}$} & \multirow{2}{*}{$\begin{array}{l}\text { Rim } \\
26.2\end{array}$} & \multirow{2}{*}{$\begin{array}{c}\text { Myrmekite } \\
18.21\end{array}$} & & & & \\
\hline & & & & & & & Point ID & 1.5 & Point ID & 16.3 \\
\hline $\mathrm{SiO}_{2}$ & 64.83 & 64.32 & 67.82 & 60.15 & 60.62 & 60.55 & $\mathrm{SiO}_{2}$ & 41.77 & $\mathrm{SiO}_{2}$ & 36.60 \\
\hline $\mathrm{TiO}_{2}$ & bd & 0.01 & 0.01 & 0.01 & 0.02 & bd & $\mathrm{TiO}_{2}$ & 1.71 & $\mathrm{TiO}_{2}$ & 3.76 \\
\hline $\mathrm{Al}_{2} \mathrm{O}_{3}$ & 18.78 & 19.17 & 20.20 & 25.34 & 25.02 & 25.00 & $\mathrm{Al}_{2} \mathrm{O}_{3}$ & 11.95 & $\mathrm{Al}_{2} \mathrm{O}_{3}$ & 14.09 \\
\hline $\mathrm{Fe}_{2} \mathrm{O}_{3}^{\mathrm{T}}$ & 0.08 & 0.08 & 0.06 & 0.20 & 0.18 & 0.08 & $\mathrm{FeO}^{\mathrm{T}}$ & 17.36 & $\mathrm{FeO}^{\mathrm{T}}$ & 18.61 \\
\hline $\mathrm{MnO}$ & $\mathrm{bd}$ & $\mathrm{bd}$ & bd & bd & $\mathrm{bd}$ & $\mathrm{bd}$ & $\mathrm{MnO}$ & 0.59 & $\mathrm{MnO}$ & 0.22 \\
\hline $\mathrm{MgO}$ & bd & bd & bd & bd & bd & bd & $\mathrm{MgO}$ & 9.77 & $\mathrm{MgO}$ & 12.69 \\
\hline- & - & - & - & - & - & - & $\mathrm{ZnO}$ & 0.04 & $\mathrm{ZnO}$ & 0.05 \\
\hline $\mathrm{CaO}$ & 0.02 & 0.10 & 0.27 & 6.33 & 6.15 & 6.09 & $\mathrm{CaO}$ & 11.10 & $\mathrm{CaO}$ & 0.05 \\
\hline $\mathrm{SrO}$ & 0.07 & 0.20 & 0.15 & 0.12 & 0.15 & 0.13 & - & - & - & - \\
\hline $\mathrm{BaO}$ & 0.34 & 0.53 & 0.02 & 0.03 & 0.02 & 0.04 & - & - & $\mathrm{BaO}$ & 0.29 \\
\hline $\mathrm{K}_{2} \mathrm{O}$ & 15.26 & 14.98 & 0.28 & 0.32 & 0.25 & 0.18 & $\mathrm{Na}_{2} \mathrm{O}$ & 1.53 & $\mathrm{Na}_{2} \mathrm{O}$ & 0.05 \\
\hline $\mathrm{Na}_{2} \mathrm{O}$ & 0.87 & 0.90 & 11.19 & 7.49 & 7.72 & 7.79 & $\mathrm{~K}_{2} \mathrm{O}$ & 1.60 & $\mathrm{~K}_{2} \mathrm{O}$ & 9.69 \\
\hline- & - & - & - & - & - & - & $\mathrm{F}$ & 0.02 & $\mathrm{~F}$ & 0.02 \\
\hline- & - & - & - & - & - & - & $\mathrm{Cl}$ & 0.12 & $\mathrm{Cl}$ & 0.10 \\
\hline Total & 100.26 & 100.27 & 100.01 & 100.01 & 100.13 & 99.86 & Total & 97.56 & Total & 96.23 \\
\hline- & - & - & - & - & - & - & $\mathrm{Fe}_{2} \mathrm{O}_{3}(\mathrm{c})$ & 5.94 & - & - \\
\hline- & - & - & - & - & - & - & $\mathrm{FeO}(\mathrm{c})$ & 12.01 & - & - \\
\hline- & - & - & - & - & - & - & $\mathrm{O}=(\mathrm{F}, \mathrm{Cl})$ & 0.03 & $\mathrm{O}=(\mathrm{F}, \mathrm{Cl})$ & 0.03 \\
\hline- & - & - & - & - & - & - & Total & 98.56 & Total & 96.20 \\
\hline \multicolumn{7}{|c|}{ Structural formulae (320) } & \multicolumn{2}{|c|}{$(230)^{*}$} & \multicolumn{2}{|c|}{$(110)$} \\
\hline $\mathrm{Si}$ & 11.941 & 11.865 & 11.869 & 10.712 & 10.775 & 10.784 & $\mathrm{Si}$ & 6.260 & $\mathrm{Si}$ & 2.779 \\
\hline $\mathrm{Ti}$ & 0.000 & 0.001 & 0.001 & 0.002 & 0.003 & 0.000 & ${ }^{\mathrm{IV}} \mathrm{Al}$ & 1.740 & ${ }^{\mathrm{IV}} \mathrm{Al}$ & 1.221 \\
\hline $\mathrm{Al}$ & 4.077 & 4.168 & 4.166 & 5.319 & 5.241 & 5.248 & Sum $T$ & 8.000 & Sum $T$ & 4.000 \\
\hline $\mathrm{Fe}^{3+}$ & 0.011 & 0.011 & 0.008 & 0.027 & 0.024 & 0.011 & ${ }^{\mathrm{VI}} \mathrm{Al}$ & 0.370 & ${ }^{\mathrm{vI}} \mathrm{Al}$ & 0.040 \\
\hline Sum T & 16.029 & 16.044 & 16.044 & 16.060 & 16.043 & 16.043 & $\mathrm{Ti}$ & 0.193 & $\mathrm{Ti}$ & 0.215 \\
\hline $\mathrm{Mn}$ & 0.000 & 0.000 & 0.000 & 0.001 & 0.000 & 0.000 & $\mathrm{Fe}^{3+}$ & 0.670 & - & - \\
\hline $\mathrm{Mg}$ & 0.000 & 0.000 & 0.001 & 0.000 & 0.000 & 0.000 & $\mathrm{Fe}^{2+}$ & 1.506 & $\mathrm{Fe}^{2+}$ & 1.182 \\
\hline $\mathrm{Ca}$ & 0.004 & 0.019 & 0.050 & 1.208 & 1.171 & 1.162 & $\mathrm{Mn}$ & 0.075 & $\mathrm{Mn}$ & 0.014 \\
\hline $\mathrm{Sr}$ & 0.008 & 0.021 & 0.016 & 0.013 & 0.016 & 0.014 & $\mathrm{Mg}$ & 2.183 & $\mathrm{Mg}$ & 1.437 \\
\hline $\mathrm{Ba}$ & 0.025 & 0.038 & 0.001 & 0.002 & 0.001 & 0.003 & $\mathrm{Zn}$ & 0.004 & $\mathrm{Zn}$ & 0.003 \\
\hline $\mathrm{K}$ & 3.585 & 3.525 & 0.063 & 0.073 & 0.056 & 0.040 & Sum C & 5.001 & Sum $M$ & 2.890 \\
\hline $\mathrm{Na}$ & 0.312 & 0.321 & 3.797 & 2.586 & 2.660 & 2.690 & $\mathrm{Ca}$ & 1.782 & $\mathrm{Ca}$ & 0.004 \\
\hline Sum $M$ & 3.935 & 3.924 & 3.928 & 3.882 & 3.905 & 3.909 & $\mathrm{Na}$ & 0.218 & $\mathrm{Na}$ & 0.008 \\
\hline- & - & - & - & - & - & - & $\operatorname{Sum} B$ & 2.000 & $\mathrm{~K}$ & 0.939 \\
\hline- & - & - & - & - & - & - & $\mathrm{Na}$ & 0.227 & $\mathrm{Ba}$ & 0.009 \\
\hline- & - & - & - & - & - & - & $\mathrm{K}$ & 0.306 & - & - \\
\hline- & - & - & - & - & - & - & Sum A & 0.533 & Sum I & 0.959 \\
\hline Sum Cat & 19.964 & 19.968 & 19.973 & 19.942 & 19.948 & 19.952 & Sum. Cat. & 15.534 & Sum. Cat. & 7.849 \\
\hline- & - & - & - & - & - & - & $F$ & 0.010 & $F$ & 0.005 \\
\hline- & - & - & - & - & - & - & $\mathrm{Cl}$ & 0.045 & $\mathrm{Cl}$ & 0.014 \\
\hline \multicolumn{11}{|c|}{ Molecular fractions } \\
\hline An & 0.11 & 0.48 & 1.28 & 31.22 & 30.11 & 29.84 & & & Phl & 0.50 \\
\hline $\mathrm{Ab}$ & 7.95 & 8.21 & 97.07 & 66.84 & 68.40 & 69.06 & & & Sid & 0.23 \\
\hline Or & 91.31 & 90.33 & 1.62 & 1.88 & 1.45 & 1.03 & & & Ann & 0.27 \\
\hline $\mathrm{Cn}$ & 0.63 & 0.97 & 0.03 & 0.06 & 0.03 & 0.07 & mg\# & 0.50 & mg\# & 0.55 \\
\hline
\end{tabular}

"Following Shumacher (1997), as modified Gualda \& Vlach (2005); mg\#: Mg/(Mg + Fe ${ }^{\mathrm{T}}$ ); An: anortite; Ab: albite; Or: orthoclase; Cn: celsian; Phl: phlogopite; Sid: Siderophyllite; Ann: annite; bd: below detection limit. 
Table 3. Representative wavelength dispersive spectroscopy (WDS) spot analyses (wt.\%) and structural formulae for Fe-Ti oxides in the BPs02 sample from the Bragança Paulista-type granite.

\begin{tabular}{|c|c|c|c|c|c|c|c|c|}
\hline & \multicolumn{4}{|c|}{ Association I } & \multicolumn{4}{|c|}{ Association II } \\
\hline & Hematite & $\begin{array}{l}\text { Titano- } \\
\text { hematite }\end{array}$ & $\begin{array}{l}\text { Ilmenite } \\
\text { host }\end{array}$ & $\begin{array}{l}\text { Ilmenite } \\
\text { exolution }\end{array}$ & Magnetite & $\begin{array}{l}\text { Titano- } \\
\text { hematite }\end{array}$ & $\begin{array}{l}\text { Ilmenite } \\
\text { host }\end{array}$ & $\begin{array}{l}\text { Ilmenite } \\
\text { exolution }\end{array}$ \\
\hline Point ID & qnt 21 & qnt 19 & qnt 2 & qnt 24 & qnt 35 & qnt 33 & qnt 5 & qnt 27 \\
\hline $\mathrm{SiO}_{2}$ & 0.04 & 0.05 & 0.10 & bd & bd & 0.06 & bd & 0.05 \\
\hline $\mathrm{TiO}_{2}$ & 1.00 & 7.99 & 48.14 & 47.81 & bd & 9.31 & 48.75 & 46.76 \\
\hline $\mathrm{Al}_{2} \mathrm{O}_{3}$ & 0.07 & 0.11 & bd & 0.01 & 0.25 & 0.11 & 0.01 & 0.02 \\
\hline $\mathrm{Fe}_{2} \mathrm{O}_{3}{ }^{\mathrm{T}}$ & 100.14 & - & - & - & - & - & - & - \\
\hline $\mathrm{FeO}^{\mathrm{T}}$ & & 83.20 & 48.87 & 49.13 & 92.75 & 82.20 & 45.07 & 47.30 \\
\hline $\mathrm{MnO}$ & 0.05 & 0.05 & 1.18 & 1.50 & bd & 0.39 & 3.93 & 3.81 \\
\hline $\mathrm{MgO}$ & bd & bd & 0.43 & 0.26 & 0.05 & bd & 0.48 & 0.42 \\
\hline $\mathrm{CaO}$ & bd & bd & 0.04 & bd & 0.02 & 0.05 & 0.02 & 0.02 \\
\hline $\mathrm{ZnO}$ & 0.04 & bd & 0.01 & 0.13 & bd & bd & bd & 0.12 \\
\hline $\mathrm{Nb}_{2} \mathrm{O}_{5}$ & bd & bd & 0.10 & 0.17 & bd & bd & 0.03 & bd \\
\hline Total & 101.35 & 91.40 & 98.86 & 99.00 & 93.06 & 92.12 & 98.29 & 98.50 \\
\hline $\mathrm{Fe}_{2} \mathrm{O}_{3}$ (c) & 98.17 & 84.42 & 8.30 & 9.13 & 68.67 & 82.48 & 7.87 & 11.02 \\
\hline $\mathrm{FeO}(\mathrm{c})$ & 0.87 & 7.24 & 41.40 & 40.91 & 31.0 & 7.98 & 38.99 & 37.39 \\
\hline Total & 100.26 & 99.83 & 99.69 & 99.92 & 99.94 & 100.38 & 100.08 & 99.61 \\
\hline \multicolumn{9}{|c|}{ Structural formulae* } \\
\hline $\mathrm{Si}$ & 0.002 & 0.003 & 0.005 & 0.000 & 0.000 & 0.003 & 0.000 & 0.002 \\
\hline $\mathrm{Ti}$ & 0.040 & 0.317 & 1.835 & 1.822 & 0.000 & 0.367 & 1.850 & 1.786 \\
\hline $\mathrm{Nb}$ & 0.000 & 0.000 & 0.002 & 0.004 & 0.000 & 0.000 & 0.001 & 0.000 \\
\hline Sum $T^{4+}$ & 0.042 & 0.320 & 1.842 & 1.826 & 0.000 & 0.370 & 1.850 & 1.789 \\
\hline $\mathrm{Al}$ & 0.005 & 0.007 & 0.000 & 0.001 & 0.011 & 0.007 & 0.001 & 0.001 \\
\hline $\mathrm{Fe}^{+3}$ & 3.911 & 3.353 & 0.316 & 0.348 & 1.989 & 3.253 & 0.299 & 0.421 \\
\hline Sum $M^{3+}$ & 3.915 & 3.360 & 0.316 & 0.349 & 2.000 & 3.260 & 0.299 & 0.422 \\
\hline $\mathrm{Fe}^{+2}$ & 0.039 & 0.320 & 1.754 & 1.734 & 0.997 & 0.350 & 1.645 & 1.588 \\
\hline $\mathrm{Mn}$ & 0.002 & 0.001 & 0.051 & 0.064 & 0.000 & 0.017 & 0.168 & 0.164 \\
\hline $\mathrm{Mg}$ & 0.000 & 0.000 & 0.032 & 0.020 & 0.003 & 0.000 & 0.036 & 0.032 \\
\hline $\mathrm{Ca}$ & 0.000 & 0.000 & 0.002 & 0.000 & 0.001 & 0.003 & 0.001 & 0.001 \\
\hline $\mathrm{Zn}$ & 0.002 & 0.000 & 0.001 & 0.005 & 0.000 & 0.000 & 0.000 & 0.005 \\
\hline Sum $R^{2+}$ & 0.042 & 0.320 & 1.840 & 1.822 & 1.000 & 0.370 & 1.850 & 1.789 \\
\hline Sum. Cat. & 4.000 & 4.000 & 3.999 & 3.997 & 3.000 & 4.000 & 4.000 & 4.000 \\
\hline \multicolumn{9}{|c|}{ Molecular fractions } \\
\hline Usp & - & - & - & - & 0.00 & - & - & - \\
\hline Mag & - & - & - & - & 100.00 & - & - & - \\
\hline Gk & - & 0.00 & 0.02 & 0.01 & - & 0.00 & 0.02 & 0.02 \\
\hline Hem & 1.00 & 0.84 & 0.08 & 0.09 & - & 0.82 & 0.07 & 0.11 \\
\hline Ilm & - & 0.16 & 0.88 & 0.87 & - & 0.18 & 0.82 & 0.80 \\
\hline Pph & - & 0.00 & 0.03 & 0.03 & - & 0.01 & 0.08 & 0.08 \\
\hline
\end{tabular}

*Based on 60 (hematite, titanohematite and ilmenite) and 40 (magnetite), following Carmichael \& Nicholls (1967); Usp: ulvoespinel; Gk: geikelite; Hem: hematite; Ilm: ilmenite; Pph: pyrophanite; bd: below detection limit 
differences, within errors, between the obtained results for core-core or rim-rim mineral compositions pairs (see also Fig. 11D). It is also worth mentioning that Blundy \& Holland (1990) and Holland \& Blundy (1994, $\mathrm{T}_{\mathrm{A}}$ Model) formulations give significant high pressures and/ or temperatures; a feature most probably associated with the subordinate contributions from the edenite substitution scheme in our amphibole.

The Al-in-hornblende barometry model was also tested, given its applicability to our sample, with the mineral assemblage quartz + alkali-feldspar + plagioclase + biotite + hornblende + titanite + Fe-Ti oxides. Both the classic linear and exponential models of Hammarstrom \& Zen (1986) and the revised version of Mutch et al. (2016) give similar pressures, around $510( \pm 50) \mathrm{MPa}$ (Fig. 11D); a similar value was also computed with the Anderson \& Smith (1995) method, which include $\mathrm{T}$ as a variable ( $c f$. Fig. 11A).

On the other hand, some older calibrations of the Al-inhornblende barometer (e.g., Schmidt 1992, and reference therein) give somewhat lower values and, importantly, the empirical calibrations based on whole-amphibole compositions coexisting with residual magmatic liquid, gauged with seismic data (e.g., Ridolfi et al. 2010, Ridolfi \& Renzulli 2012), for calc-alkaline volcanic rocks from recent active continental margins result in much lower, incompatible pressures ( $\leq 300 \mathrm{MPa}$, see also Erdmann et al. 2014) and

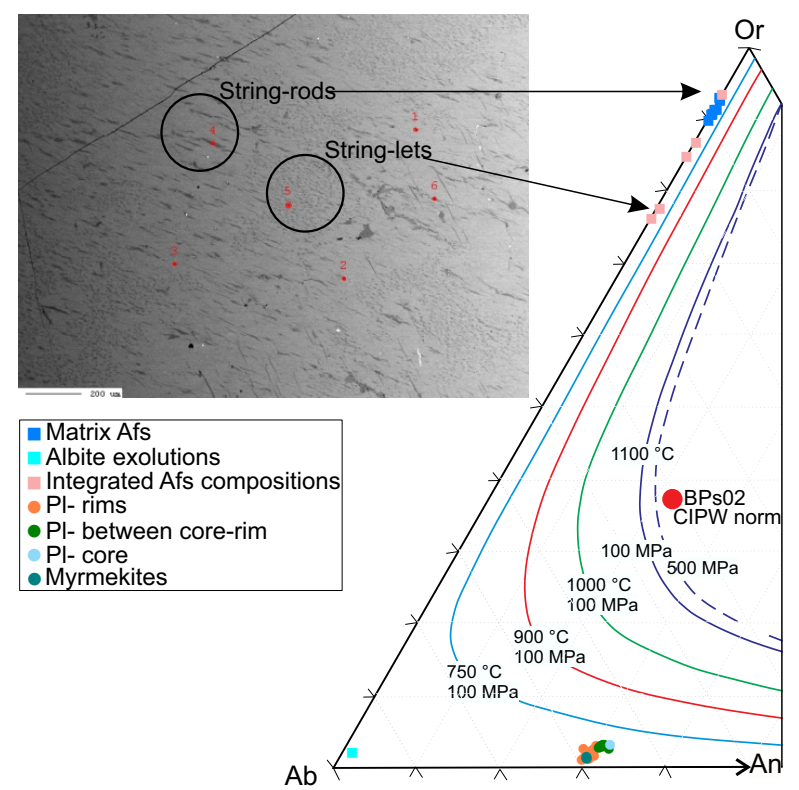

Figure 7. Ab-Or-An ternary diagram showing the measured feldspar compositional variations in the BPs02 studied sample. Back-scattered electronic (BSE) image (upper left) details contrasted albite exsolution patterns in alkali feldspar as discussed in the text. Isotherms were plotted according to Fuhrman \& Lindsley (1988).
A
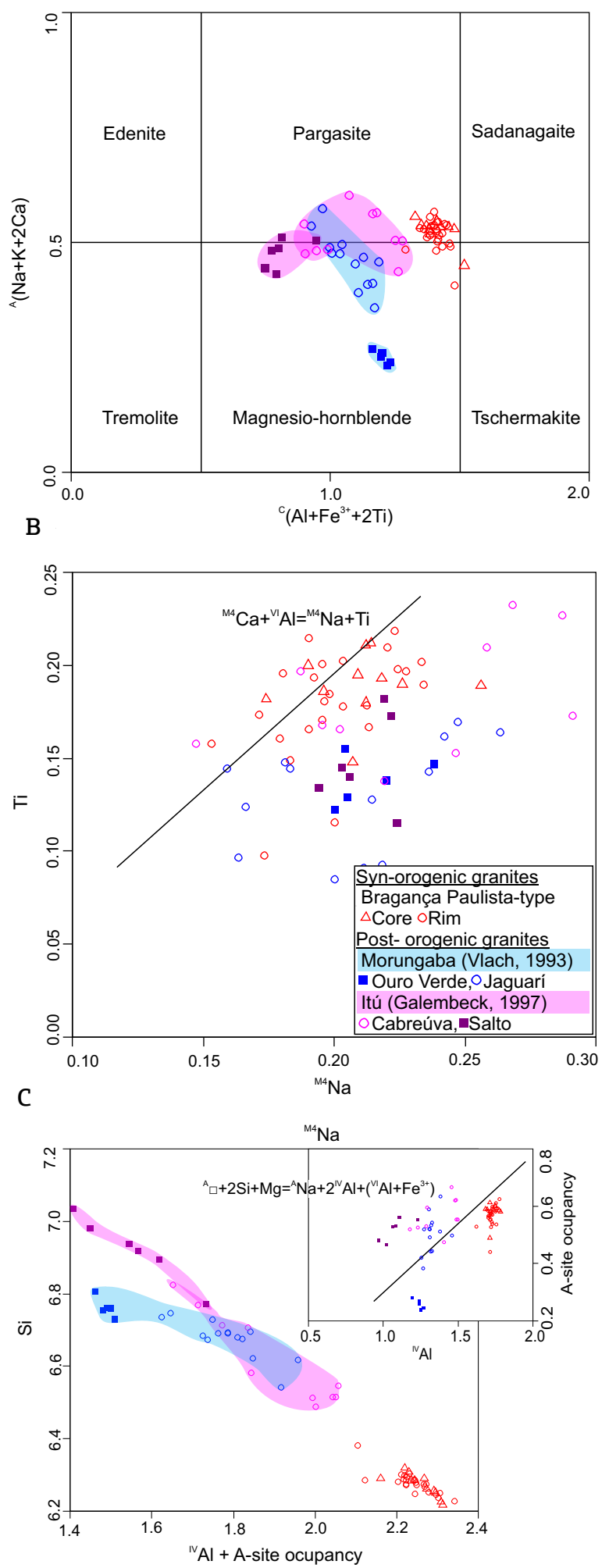

Figure 8. Compositional characteristics of amphiboles from syn- to post- orogenic granites. (A) Classification diagram following Hawthorne et al. (2012). (B and C) diagrams depict the ${ }^{\mathrm{M} 4} \mathrm{Ca}+{ }^{\mathrm{VI}} \mathrm{Al}={ }^{\mathrm{M} 4} \mathrm{Na}+\mathrm{Ti}$ (CANT) and hastingsitepargasite-type substitutions, according to Vyhnal et al. (1991) and Vlach (1993). See discussion in the text. 
A

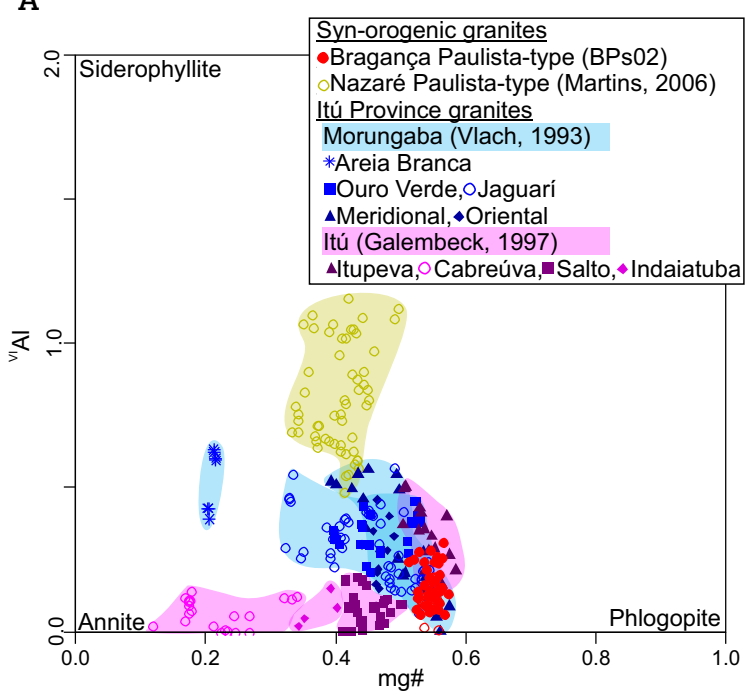

B

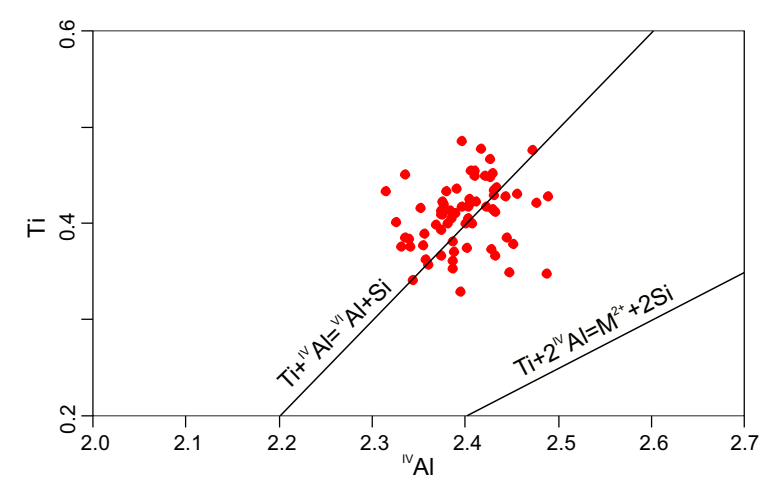

C

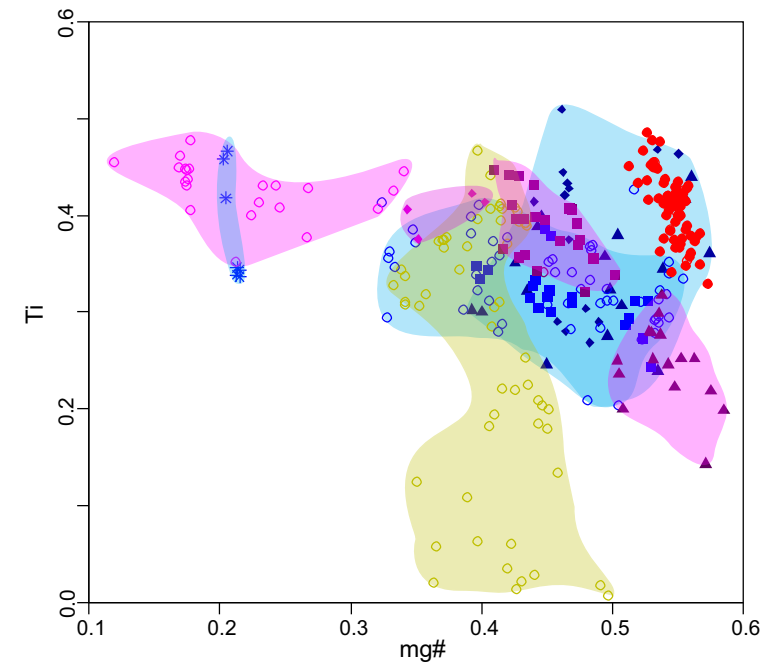

Figure 9. Compositional characteristics of biotites from syn- to post- orogenic granites. (A) Classification diagram following Guidotti (1984). (B) Lines of the two ideal $\mathrm{Ti}+{ }^{\mathrm{IV}} \mathrm{Al}$ possible coupled substitutions in biotite. (C) Ti vs. $\mathrm{mg} \#\left(\mathrm{Mg} /\left(\mathrm{Mg}+\mathrm{Fe}^{\mathrm{T}}\right)\right.$, cationic plot. See text for discussion. higher temperatures (902 and $841^{\circ} \mathrm{C}$, respectively) for our amphibole compositions.

\section{Accessory-phase saturation and liquidus temperatures}

Zircon and apatite saturation thermometry results for the BPB granites are resumed in Fig. 11B. As depicted, apatite saturation temperatures (Watson \& Harrison 1984) cover the $920-1,025^{\circ} \mathrm{C}$ range and are always higher than zircon equivalents, computed according Watson \& Harrison (1983), in the $609-820^{\circ} \mathrm{C}$ range. Of importance, these latter values will still decrease, by ca. $60-90^{\circ} \mathrm{C}$, if calculated with the revised formulae of Boehnke et al. (2013). It is worth to mention that the zircon saturation temperature estimated according the latter authors gives a value close to the obtained through the amphibole-plagioclase thermometer $\left(\mathrm{ca} .755^{\circ} \mathrm{C}\right)$ in our sample.

As compared with the available previous whole-rock data set, our sample has the highest for zircon saturation temperatures, even considering their intermediate composition within the complete data set (see also Fig. 5). Of note, several of the obtained values for zircon saturation temperatures in this data set are surprisingly lower for their $\mathrm{SiO}_{2}$ contents, some even lower than the expected temperatures for granite minimum melts, reinforcing the aforementioned concern in older analysis issues. On the other hand, the results for apatite are of easy interpretation in general as compared with zircon results. As in the latter case, the obtained temperatures could represent the

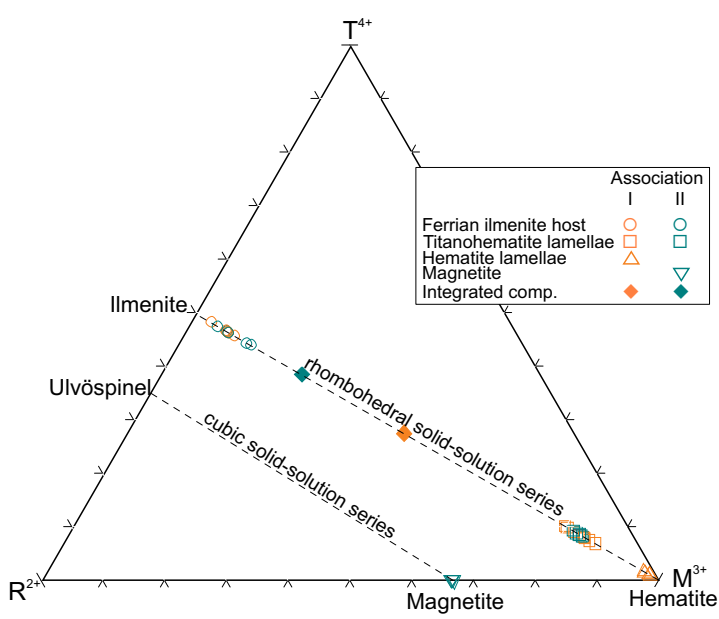

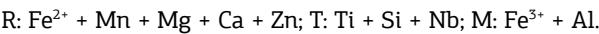

Figure 10. $\mathrm{R}^{2+}-\mathrm{T}^{4+}-\mathrm{M}^{3+}$ ternary diagram illustrating $\mathrm{Fe}-\mathrm{Ti}$ oxides compositional variations in the $\mathrm{BPs} 02$ sample, emphasizing the contrasted textural associations described in the text, and the integrated compositions for rombohedral oxides constituting the $\mathrm{Fe}-\mathrm{Ti}$ oxide associations I and II. See text. 
temperatures of source melting, in dependence of source zircon partial or complete dissolution in inheritance-rich magmas (Miller et al. 2003).

The difference between apatite $\left(973^{\circ} \mathrm{C}\right)$ and zircon $\left(811^{\circ} \mathrm{C}\right)$ saturation temperatures is compatible with the early crystallization of apatite, as deduced from textural relations (see petrographic section), and it is very significant. Considering that sample and parental granite melt compositions approaches each other, these values and the amphibole-plagioclase equilibrium close-to-solidus temperature $\left(\mathrm{ca} .755^{\circ} \mathrm{C}\right)$ may suggest a considerable magma crystallization temperature span.

Liquidus temperatures were further estimated from whole-rock chemical compositions (including volatile contents, $c f$. next section) through the empirical geochemical formulation of Molina et al. (2015) and the thermodynamic Rhyolite-MELTS model (Ghiorso \& Gualda 2015). Applying the first model (cf. Fig. 11B), $985^{\circ} \mathrm{C}$ is estimated, a value approaching well our apatite saturation temperature.
A
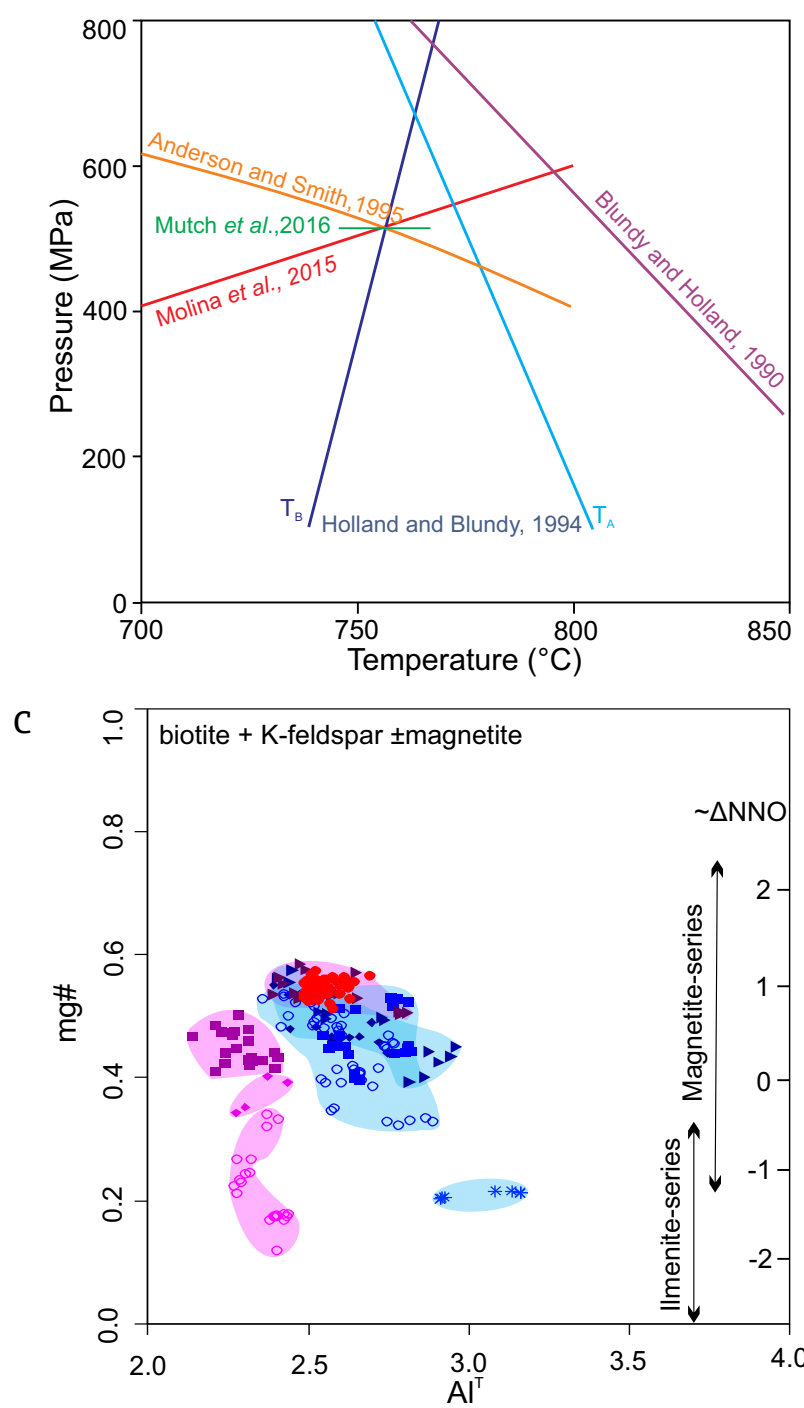

B
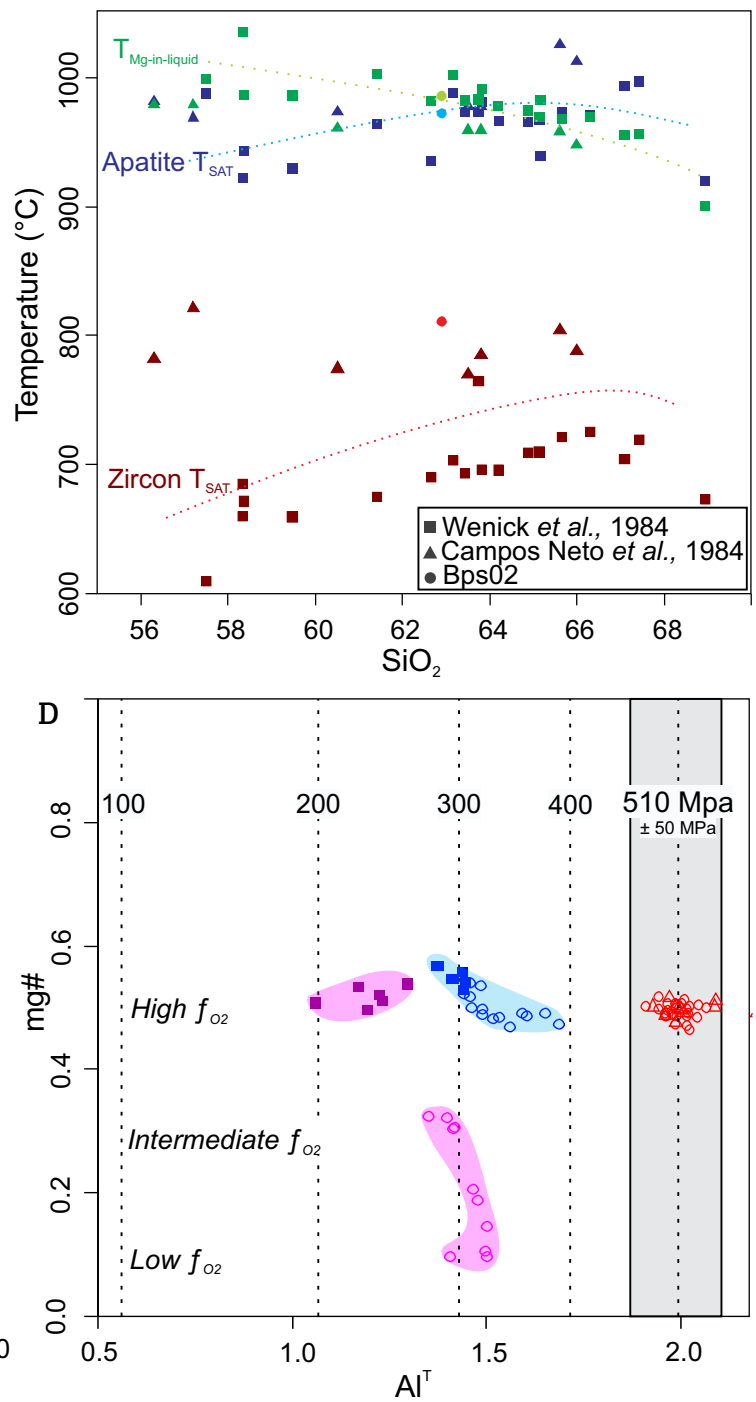

Figure 11. Selected diagrams depicting the main intensive crystallization parameter estimates. (A) Geothermobarometry based on amphibole-plagioclase equilibrium and Al-in-amphibole barometry, according to the indicated proposed calibrations. (B) Zircon and apatite saturation temperatures (Watson \& Harrison 1983, 1984), and Mg-in-liquid temperature vs. $\mathrm{SiO}_{2}$ (Molina et al. 2015). (C) Semi-quantitative redox conditions as indicated in the $\mathrm{Al}^{\mathrm{T}}$ vs. $\mathrm{mg} \#\left(\mathrm{Mg} / \mathrm{Fe}^{\mathrm{T}}+\mathrm{Mg}\right.$ ) cationic plot for biotite, according to Anderson et al. (2008), except for the reference to the nickel-nickel oxide (NNO) rather quartz-fayalite-magnetite (QFM) buffer, symbols as in Figure 9. (D) $\mathrm{Al}^{\mathrm{T}}$ vs. $\mathrm{mg} \#\left(\mathrm{Mg} / \mathrm{Fe}^{\mathrm{T}}+\mathrm{Mg}\right)$ cationic plot for amphibole with qualitative redox conditions, as inferred according to Anderson \& Smith (1995), and isobaric dashed lines based on the revised Al-in-amphibole barometer (Mutch et al. 2016) with uncertainties (gray area). Symbols as in Figure 8. 
The second model, in its turn, gives a well higher temperature $\left(1,150^{\circ} \mathrm{C}\right)$ however, which may suggest that our sample is not representative in full of the original melt composition from which it crystallized.

\section{Redox conditions}

In magnetite-bearing granites, biotite and amphibole compositions, expressed by the mg\# parameter, may give semi-quantitative or, at the least, qualitative $f_{\mathrm{O} 2}$ information, because the $\mathrm{Mg} /(\mathrm{Mg}+\mathrm{Fe})$ ratios of mafic silicate minerals depend, among other factors, on redox conditions during their crystallization (e.g., Wones 1981, Anderson et al. 2008). Our biotite $(0.51 \leq \mathrm{mg} \# \leq 0.57)$ compositions point to $f_{\mathrm{O} 2}$ values close to $\triangle \mathrm{NNO}+1$ (Fig. $11 \mathrm{C}$ ). The negative correlation between Ti contents and $\mathrm{mg \#} \mathrm{in} \mathrm{our} \mathrm{biotites} \mathrm{also} \mathrm{suggests}$ an oxidized cooling path, as in the crystallizing system it is expected that Ti-in-biotite would decrease with temperature (Henry et al. 2005, Nachit et al. 2005). The magnesio-hastingsite, with $0.47 \leq \mathrm{mg} \# \leq 0.52$, also indicate a relatively high $f_{\mathrm{O} 2}$ (Fig. 11D). The empirical thermobarometric calibration, based on whole-amphibole compositions, developed by Ridolfi et al. (2010), yield similar oxidizing values $(\approx \Delta \mathrm{NNO}+0)$. These estimates are compatible, as expected, to the so-called magnetite-bearing series granites (Ishihara 1977), crystallized close or above the nickel-nickel oxide (NNO) buffer, even magnetite being subordinate to hemo-ilmenite in our sample.

Original oxygen fugacity and the T- $f_{\mathrm{O} 2}$ path during cooling are the main parameters controlling the Fe-Ti oxide assemblages, as well as their textural and compositional fingerprints. The obtained integrated composition of hemo-ilmenite from Associations I and II were used to try to reconstruct of the redox state of the early magmatic stage. These compositions may be well representative of the primary ones, as both associations present solely in situ sub-solidus re-equilibration without major remobilization within the whole system, a normal feature in plutonic rocks (Frost 1991a, 1991b).

Assuming such hypothesis, the occurrence of hemo-ilmenite and magnetite in the studied sample indicates initial conditions relatively oxidized in the crystallizing system. The interpretation of the observed Fe-Ti oxide associations is not so straightforward, however. The relatively higher content of hematite in Association I ( $\mathrm{X}_{\mathrm{Hem}}$-rich hemo-ilmenite) as compared with Association II (magnetite $+\mathrm{X}_{\mathrm{Ilm}}{ }^{-}$ rich hemo-ilmenite) suggests relative higher $f_{\mathrm{O} 2}$ conditions (Ghiorso \& Sack 1991, Ghiorso \& Evans 2008, Sauerzapf et al. 2008, Broska \& Petrík 2011). On the other hand, the pyrophanite molecular content in ilmenite increases with $f_{\mathrm{O} 2}$ (Czamanske \& Mihálik 1972, Harlov \& Hansen 2005, Mehdilo et al. 2015), and the ilmenite in Association I is relatively Mn-poor. As Mn has great affinity for the ilmenite structure as compared to Ca-amphibole and biotite (e.g.,
Czamanske \& Mihálik 1972, Harlov \& Hansen 2005, Deer et al. 2011), this may indicate that Association II had crystallized earlier than Association I and sequestered a significant quantity of the $\mathrm{Mn}$ available in the system. In addition, redox conditions in originally oxidized melts may also increase through the reaction $6 \mathrm{Fe}_{2} \mathrm{O}_{3 \text { (melt) }}=4 \mathrm{Fe}_{3} \mathrm{O}_{4 \text { (magnetite) }}+$ $\mathrm{O}_{2 \text { (melt) }}$ (cf. Richards 2015).

The textural and chemical features of our hemo-ilmenite indicate late- to post-magmatic inter- and oxide-oxide re-equilibration, which approaches their pure end-members (ferrian ilmenite and titanohematite/hematite) and left ilmenite exsolutions-free portions at magnetite-ferrian ilmenite contacts, respectively. In the first case, there are not textural evidences indicating which among the hematite and titanohematite lamellae exsolved first in both Fe-Ti oxide associations during cooling. Nevertheless, arguably the hematite lamellae were formed first, as it represents the most pure end-member (cf. Geuna et al. 2008, McEnroe et al. 2009). In the second case, re-equilibrium can be due through the $\mathrm{Fe}^{2+} \mathrm{Ti} \leftrightarrow 2 \mathrm{Fe}^{3+}$ exchange between ferrian ilmenite and magnetite (e.g., Frost 1991b, Korneliussen et al. 2000).

\section{Halogen fugacity}

Halogen fugacity ratios $\left(f_{\mathrm{H} 2 \mathrm{O}} / f_{\mathrm{HF}}, f_{\mathrm{H} 2 \mathrm{O}} / f_{\mathrm{HCl}}\right.$ and $f_{\mathrm{HF}} /$ $f_{\mathrm{HCl}}$ ) were estimated through the equilibrium between melt and biotite, using the formalism presented by Munoz (1992), and depicted in Fig. 12. It must be pointed out that the F-in biotite contents are very low in our sample, approaching $\mathrm{F}$ detection limits even using TAP $(\mathrm{H})$ analyzer crystals. Using the maximum measured F content (ca. 200 ppm), minimum and maximum values for $f_{\mathrm{H} 2 \mathrm{O}} / f_{\mathrm{HF}}$ and $f_{\mathrm{HF}} / f_{\mathrm{HCl}}$ ratios may be roughly estimated, and we obtain $f_{\mathrm{H} 2 \mathrm{O}} / f_{\mathrm{HF}} \geq 10^{5.8}, 10^{3.5}$ $\leq f_{\mathrm{H} 2 \mathrm{O}} / f_{\mathrm{HCl}} \leq 10^{3.8}$ and $f_{\mathrm{HF}} / f_{\mathrm{HCl}} \leq 10^{-2.2}$.

The fluorine and chlorine relative contents in biotite and amphibole from our sample are very similar and may suggest co-crystallization. Biotite in amphibole-bearing granites are relatively F-poor $(\leq 0.04$ wt. $\%)$ and Cl-rich ( $\geq 0.33$ wt.\%), in general as compared to muscovite- and biotite-bearing granites (Teiber et al. 2014). For instance, high $\mathrm{F} / \mathrm{Cl}$ ratios in biotite $\left(10^{-2.8} \leq f_{\mathrm{HF}} / f_{\mathrm{HCl}} \leq 10^{-0.31}\right)$ are the most typical feature of crustal metasedimentary source rocks as the ones that generated the Nazaré Paulista-type granites. Our biotite, however, has low to medium $\mathrm{Cl}$ contents $(\leq 0.18$ wt. $\%)$.

Vlach \& Ulbrich (1994) calculated $10^{3.5} \leq f_{\mathrm{H} 2 \mathrm{O}} / f_{\mathrm{HF}} \leq$ $10^{4.0}$ for granites from the Morungaba area using a previous model of Munoz (1984). However, as stated by Munoz (1992), his older model yields somewhat lower ratios. Unfortunately, the available biotite compositions from the post-orogenic granites did not include $\mathrm{Cl}$ measurements and do not allow the application of the new model. As a 
reference for comparison, applying the first Munoz's formulation, $f_{\mathrm{H} 2 \mathrm{O}} / f_{\mathrm{HF}} \geq 10^{5.5}$ is obtained for our sample, suggesting higher $f_{\mathrm{H} 2 \mathrm{O}} / f_{\mathrm{HF}}$ values for the syn-, as compared with the post-orogenic magmatism. In general, comparing also F contents in biotite from syn-orogenic and post-orogenic granites in the studied area, one may conclude the post-orogenic granites (Itu, Morungaba) were generated from relatively F-rich magmas.

\section{DISCUSSION}

The results above suggest that the syn-orogenic magmatism Bragança Paulista-type was emplaced under a lithostatic pressure of ca. $500 \mathrm{MPa}$, corresponding to a ca. 14-16 km depth, compatible with the observed textures and the lowrange compositional variations registered in plagioclase, calcic amphibole and biotite, which indicate a relatively slow temperature decreasing gradient during crystallization, as expected in moderate to high P environments.

Barometric data for the regional metamorphism obtained by Martins (2006, see also Martins et al. 2009) through the garnet-Al silicate-plagioclase (GASP) geobarometer point to lithostatic pressures around $750 \mathrm{MPa}$. Some among these leucogranites were emplaced under local extensive structures and do contain andalusite, while others present sillimanite; no coexistence of andalusite and sillimanite was yet reported. Andalusite-bearing muscovite leucogranites may be formed up to ca. $400-450 \mathrm{MPa}$ from water-satured, low-temperature (ca. $630-640^{\circ} \mathrm{C}$ ) peraluminous melts (Clarke et al. 2005). Of importance, the metamorphic peak was dated about 630-620 Ma, while some leucogranites have emplacement ages down to $610 \mathrm{Ma}$ (Janasi 1999, Vlach \& Gualda 2000, Martins et al. 2009), so the generation of these peraluminous melts took place possibly along a clockwise evolutionary P-T-t path (Janasi et al. 2005, Martins et al. 2009).
On the other hand, the late- to post-orogenic magmatism in the area, represented, respectively, by the Ouro Verde Complex and the Jaguari Pluton from the Morungaba granites (Vlach 1993, Vlach \& Ulbrich 1994) and the Meridional Morungaba plutons and the Salto and Cabreúva plutons from the Itu Batholith (Vlach 1993, Vlach \& Ulbrich 1994, Galembeck et al. 1997, Janasi et al. 2009), were emplaced at relatively shallower crustal levels (corresponding to ca. 300 $\mathrm{MPa}$, late-orogenic plutons; down to ca. $200 \mathrm{MPa}$, typically post-orogenic plutons). Thus, considering a time span of about 20-30 Ma between the main syn- and post-orogenic granite emplacement events in the area (e.g., Janasi et al. 2009, Martins et al. 2009, Vlach \& Gualda 2000, recent unpublished data), post-closure uplift (in the sense of Pitcher 1982) relative ratios averaging 0.2 to $0.3 \mathrm{~km} / \mathrm{Ma}$ may be estimated since the main syn- until the post-orogenic granite magmatism. A similar relative ratio may be estimated between the main regional metamorphism and the syn-orogenic magmatism in the area and neighboring.

The calc-alkaline syn- and late-orogenic granites, as well as the post-orogenic biotite granites and, among them, typical A-type granites, as the Salto Pluton, in the Itu Batholith, were formed by the crystallization of relatively oxidizing magmas, under ca. $0 \leq \Delta \mathrm{NNO} \leq 1$ (Vlach \& Ulbrich 1994, Galembeck et al. 1997, Janasi et al. 2009), values akin to the titanite-magnetite-quartz-amphibole-ilmenite (TMQAI) buffer, as defined by Noyes et al. (1983) and Wones (1989). Up to now, the available data do not allow better define measurable ox-red differences among the syn-, late- and post-orogenic granites. However, mineral assemblage suggests the possibility of somewhat higher oxidation states in the case of the relatively evolved titanite-magnetite-bearing biotite granites. A remarkable exception is the Cabreúva Pluton, in the Itu Batholith, with biotite compositions akin to A-type granites with intermediate to reduced character (Galembeck et al. 1997, Janasi et al. 2009). As expected, the anatetic
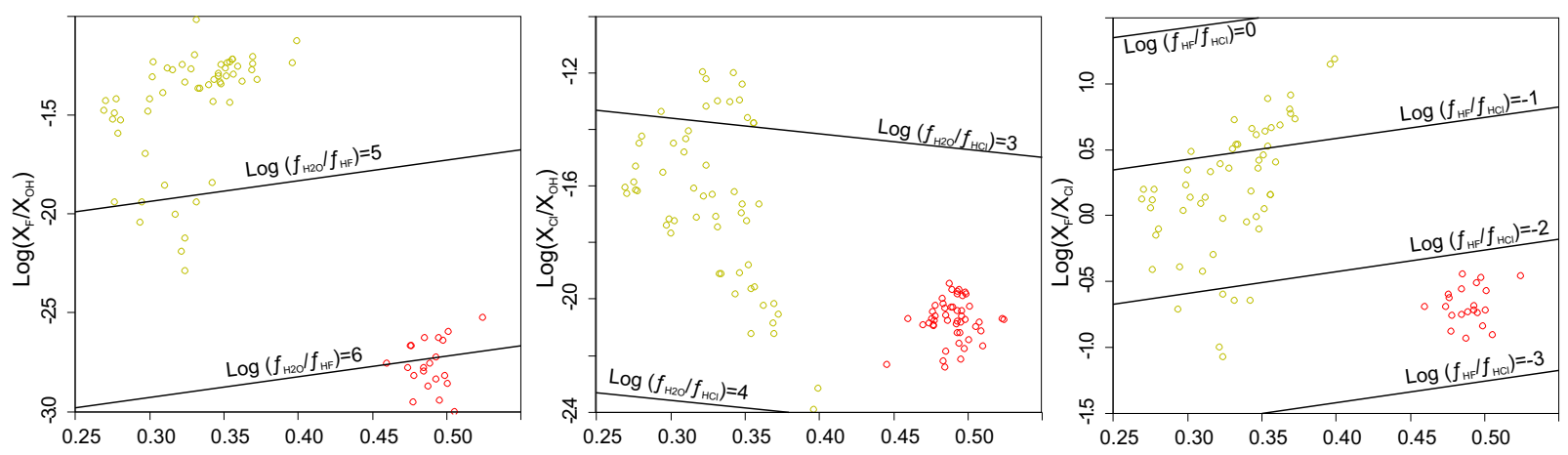

Figure 12. Octahedral Mg mole fraction vs. halogen mole fraction in hydroxyl sites in biotite from the synorogenic granites. Equal ratio lines calculated following Munoz (1992), assuming biotite-fluid equilibrium at $750^{\circ} \mathrm{C}$. Biotite analyses were plotted with $\mathrm{F} \geq 110 \mathrm{ppm}$. Symbols as in Figure 9. 
leucogranites (Nazaré Paulista-type) generated by melting of metasedimentary sequences and related occurrences at the Morungaba regions (Areia Branca Pluton and Meridional Occurrences, $c f$. Vlach (1993) and Vlach \& Ulbrich (1994)) were formed under more reduced conditions and comprise mainly granites of the ilmenite-series series of Ishihara (1977). Oxidizing conditions are the most typical feature of metaluminous, magnesian, calc-alkaline granites related to subduction environments and the associated late biotite granites emplaced during the post-orogenic uplift stages, which contain, in variable amounts, contributions from both the continental crust and the mantle in their compositions.

\section{SUMMARY AND CONCLUSIONS}

Detailed petrographic and geochemical studies for a typical sample (hornblende biotite monzogranite, with Fe-Ti oxides, allanite, apatite, titanite, zircon and some sulphide), representative of the main Bragança Paulistatype syn-orogenic magmatism from the southern Brasilia Orogen, indicates that:

- granites present geochemical fingerprints akin to high-K, magnesian, metaluminous, calc-alkaline series. The main granite type was emplaced at medium crustal levels, corresponding to ca. $510 \pm 60 \mathrm{MPa}(\approx 14-16 \mathrm{~km}$ depth); the original magma crystallized under relatively low cooling rates, within an arguably temperature interval from ca. $975^{\circ} \mathrm{C}$ (close-to-liquidus) to ca. $755^{\circ} \mathrm{C}$ (close-to-solidus); magmas crystallized under middle- $f_{\mathrm{H} 2 \mathrm{O}}$ and $-f_{\mathrm{HCl}}$, low- $f_{\mathrm{HF}}$ and oxidizing conditions, compatible with $0 \leq \Delta \mathrm{NNO} \leq 1$. Ilmenite-hematite progressive re-equilibrium with decreasing temperatures suggests an oxidizing evolving trend.
The estimate ox-red conditions are similar to those regionally observed for most late- to post-orogenic granites from the Itu Province;

- the integration of barometric and age data available for the main regional metamorphism and magmatism in the studied area suggest a post-closure uplift relative ratio about 0.2 to $0.3 \mathrm{~km} / \mathrm{Ma}$, from the main regional metamorphism to the post-orogenic granite emplacement periods.

The presented results may be taken, with the deserved caution, as representative of the main Bragança Paulista-type magmatism. However, similar studies considering the whole granite varieties, new whole-rock and mineral geochemical should be carried out to better constrain the emplacement of this extensive magmatism and its geodynamic implications.

\section{ACKNOWLEDGEMENTS}

The authors thank the GeoAnalitica/USP staff for support during sample preparation and analysis. SalazarNaranjo thanks Brazilian National Council for Scientific and Technological Development (CNPq) for a Master scholarship (Process no. 159228/2014-0). S. Vlach thanks CNPq (Process no. 309557/2014-1). Authors thank R. Dal'Agnol for his invaluable comments and criticism and another anonymous reviewer; both help to improve the first manuscript version.

\section{SUPPLEMENTARY DATA}

Supplementary data associated with this article can be found in the online version: Supplementary Table A1.

\section{REFERENCES}

Abdel-Rahman A.F.M. 1994. Nature of biotites from alkaline, calcalkaline, and peraluminous magmas. Journal of Petrology, 35(2):525541. https://doi.org/10.1093/petrology/35.2.525

Anderson J.L., Barth A.P., Wooden J.L., Mazdab F. 2008. Thermometers and Thermobarometers in Granitic Systems. Reviews in Mineralogy and Geochemistry, 69(1):121-142. https://doi.org/10.2138/rmg.2008.69.4

Anderson J.L. \& Smith D.R. 1995. The effects of temperature and fO2 on the Al-in-hornblende barometer. American Mineralogist, 80(56):549-559. http://dx.doi.org/10.2138/am-1995-5-614

Artur A.C., Ebert H.D., Wernick E. 1991. Magmatismo e Tectónica no Complexo Socorro (SP/MG). In: Simpósio de Geologia do Sudeste, 2., São Paulo. Atas... São Paulo, Sociedade Brasileira de Geologia.
Artur A.C., Wernick E., Hôrmann P.K., Weber-Diefenbach K. 1993. Associações Plutônicas do Complexo Granitoide Socorro (Estados de São Paulo e Minas Gerais, SE Brasil). Revista Brasileira de Geociências, 23(3):265-273.

Balsley J.R. \& Buddington A.F. 1958. Iron-titanium oxide minerals, rocks, and aeromagnetic anomalies of the Adirondack area, New York. Economic Geology, 53(7):777-805. https://doi.org/10.2113/ gsecongeo.53.7.777

Blundy J.D. \& Holland T.J.B. 1990. Calcic amphibole equilibria and a new amphibole-plagioclase geothermometer. Contributions to Mineralogy and Petrology, 104(2):208-224. https://doi.org/10.1007/BF00306444

Boehnke P., Watson E.B., Trail D., Harrison T.M., Schmitt A.K. 2013. Zircon saturation re-revisited. Chemical Geology, 351:324-334. https://doi.org/10.1016/j.chemgeo.2013.05.028 
Broska I. \& Petrík I. 2011. Accessory Fe-Ti oxides in the WestCarpathian I-type granitoids: Witnesses of the granite mixing and late oxidation processes. Mineralogy and Petrology, 102(1-4):87-97. https://doi.org/10.1007/s00710-011-0158-6

Campos Neto M. da C., Basei M.A.S., Assis Janasi V. de, Moraes R. 2011. Orogen migration and tectonic setting of the Andrelândia Nappe system: An Ediacaran western Gondwana collage, south of São Francisco craton. Journal of South American Earth Sciences, 32(4):393-406. https://doi.org/10.1016/j.jsames.2011.02.006

Campos Neto M. da C., Cioff C.R., Moraes R., da Motta R.G., Siga O., Basei M.A.S. 2010. Structural and metamorphic control on the exhumation of high-P granulites: The Carvalhos Klippe example, from the oriental Andrelândia Nappe System, southern portion of the Brasília Orogen, Brazil. Precambrian Research, 180(3-4):125142. https://doi.org/10.1016/j.precamres.2010.05.010

Campos Neto M.D.C. \& Caby R. 1999. Neoproterozoic high-pressure metamorphism and tectonic constraint from the nappe system south of the Sao Francisco Craton, southeast Brazil. Precambrian Research, 97(1-2):3-26. http://dx.doi.org/10.1016/S0301-9268(99)00010-8

Campos Neto M. da C., Heredia de Figueiredo M.C., Basei M.A.S., Alves F.R. 1984. Os granitóides da região de Bragança Paulista, SP. In: Congresso Brasileiro de Geologia, 33. Anais..

Campos Neto M. da C., Janasi V.D.A., Bassei M.A.S., \& Siga Jr. O. 2007. Sistema de nappes Andrelândia, setor oriental: litoestratigrafia e posição estratigráfica. Revista Brasileira de Geociências, 37(4 Supl.):47-60.

Campos Neto M. da C., Stipp Basei M.A., Farias Vlach S.R., Caby R., Szabó G.A.J., Vasconcelos P. 2004. Migração de Orógenos e Superposição de Orogêneses: Um Esboço da Colagem Brasiliana no Sul do Cráton do São Francisco, SE - Brasil. Geologia USP - Série Científica, 4(1):13-40. https://doi.org/10.5327/S1519-874×2004000100002

Carmichael I.S.E. \& Nicholls J. 1967. Iron-titanium oxides and oxygen fugacities in volcanic rocks. Journal of Geophysical Research, 72(18):4665-4687. https://doi.org/10.1029/JZ072i018p04665

Clarke D.B., Dorais M., Barbarin B., Barker D., Cesare B., Clarke G., El Baghdadi M., Erdmann S., Förster H.J., Gaeta M., Gottesmann B., Jamieson R.A., Kontak D.J., Koller F., Gomes C.L., London D., Morgan VI G.B., Neves L.J.P.F., Pattison D.R.M., Pereira A.J.S.C., Pichavant M., Rapela C.W., Renno A.D., Richards S., Roberts M., Rottura A., Saavedra J., Sial A.N., Toselli A.J., Ugidos J.M., Uher P., Villaseca C., Visonà D., Whitney D.L., Williamson B., Woodard H.H. 2005. Occurrence and origin of andalusite in peraluminous felsic igneous rocks. Journal of Petrology, 46(3):441-472. https://doi.org/10.1093/ petrology/egh083

Czamanske G.K. \& Mihálik P. 1972. Oxidation during magnetic differentiation, Finnmarka Complex, Oslo area, Norway. Pt I. The Opaque Oxides. Journal of Petrology, 13(3):493-509. https://doi. org/10.1093/petrology/13.3.493

Deer W.A., Howie R.A., Zussman J. 1997. Rock-forming minerals: Double Chain Silicates. $2^{\mathrm{a}}$ ed. London, The Geological Society. v. 2B.

Deer W., Howie R.A., Zussman J., Bowles J., Vaughan D. 2011. RockForming Minerals: Non-Silicates: Oxides, Hydroxides and Sulphides. London, Geological Society of London. v. 5A.

Del Lama E.A., Zanardo A., Oliveira M.A.F., Morales N. 2000. Exhumation of high-pressure granulites of the guaxupé complex, southeastern Brazil. Geological Journal, 35(3-4):231-249. https://doi.org/10.1002/gj.859

Ebert H.D., Chemale F., Babinski M., Artur A.C., Van Schmus W.R. 1996. Tectonic setting and U/Pb zircon dating of the plutonic Socorro Complex in the Transpressive Rio Paraíba do Sul Shear Belt, SE Brazil. Tectonics, 15(3):688-699. http://dx.doi.org/10.1029/95TC03247

Erdmann S., Martel C., Pichavant M., Kushnir A. 2014. Amphibole as an archivist of magmatic crystallization conditions: Problems, potential, and implications for inferring magma storage prior to the paroxysmal 2010 eruption of Mount Merapi, Indonesia. Contributions to Mineralogy and Petrology, 167(6):1-23. https://doi.org/10.1007/s00410-014-1016-4

Frost B.R. 1991a. Introduction to oxygen fugacity and its petrologic importance. Reviews in Mineralogy and Geochemistry, 25(1):1-10.

Frost B.R. 1991b. Magnetic petrology; factors that control the occurrence of magnetite in crustal rocks. Reviews in Mineralogy and Geochemistry, 25(1):489-509.

Frost B.R., Barnes C.G., Collins W.J., Arculus R.J., Ellis D.J., Frost C.D. 2001. A Geochemical Classification for Granitic Rocks. Journal of Petrology, 42(11):2033-2048. https://doi.org/10.1093/ petrology/42.11.2033

Fuhrman M.L. \& Lindsley D.H. 1988. Ternary-feldspar modeling and thermometry. American Mineralogist, 73:201-215.

Galembeck T.M.B. 1997. O complexo múltiplo, centrado e plurisserial Itu-SP. PhD Thesis, Universidade Estadual Paulista "Júlio de Mesquita Filho", Rio Claro, 374 p.

Galembeck T.M.B., Wernick E., Hörmann P.K. 1997. Chemistry of Biotites and Whole Rocks from the Rapakivi Itu Complex (Late Precambrian), State of São Paulo, SE Brazil. Anais da Academia Brasileira de Ciências, 69(3):414-429.

Geuna S.E., McEnroe S.A., Robinson P., Escosteguy L.D. 2008. Magnetic petrology of the Devonian Achala Batholith, Argentina: Titanohaematite as an indicator of highly oxidized magma during crystallization and cooling. Geophysical Journal International, 175(3):925-941. https://doi.org/10.1111/j.1365-246X.2008.03964.X

Ghiorso M.S. \& Evans B.W. 2008. Thermodynamics of rhombohedral oxide solid solutions and a revision of the Fe-Ti two-oxide geothermometer and oxygen-barometer. American Journal of Science, 308(9):957-1039. https://doi.org/10.2475/09.2008.01

Ghiorso M.S. \& Gualda G.A.R. 2015. An H2O-CO2 mixed fluid saturation model compatible with rhyolite-MELTS. Contributions to Mineralogy and Petrology, 169(6):53. http://dx.doi.org/10.1007/ s00410-015-1141-8

Ghiorso M.S. \& Sack R.O. 1991. Fe-Ti oxide geothermometry: thermodynamic formulation and the estimation of intensive variables in silicic magmas. Contributions to Mineralogy and Petrology, 108(4):485-510. https://doi.org/10.1007/BF00303452

Gualda G.A.R. 2001. Evolução petrográfica e mineralógica das associações alcalina e aluminosa dos granitos tipo-A da Graciosa, PR. Master's Dissertation, Universidade de São Paulo, São Paulo, 274 p. http://dx.doi.org/10.11606/D.44.2001.tde-02102015-111623

Gualda G.A.R. \& Vlach S.R.F. 2005. Stoichiometry-based estimates of ferric iron in calcic, sodic-calcic and sodic amphiboles: A comparison of various methods. Anais da Academia Brasileira de Ciências, 77(3):521-534. http://dx.doi.org/10.1590/ S0001-37652005000300012

Gualda G.A.R. \& Vlach S.R.F. 2007. The Serra da Graciosa A-type Granites and Syenites, southern Brazil Part 2: Petrographic and mineralogical evolution of the alkaline and aluminous associations. Lithos, 93(3-4):310-327. http://dx.doi.org/10.1016/j. lithos.2006.06.002

Guidotti C.V. 1984. Micas in metamorphic rocks. Reviews in Mineralogy and Geochemistry, 13(1):357-467.

Hackspacher P.C., Fetter A.H., Ebert H.D., Janasi V. de A., Dantas E.L., de Oliveira M.A.F., Braga I.F., Negri F. de A. 2003. Magmatismo há ca. 660 - 640 Ma no Domínio Socorro: Registros de convergênciacolisional na Aglutinação do Gondwana Ocidental. Geologia USP - Série Científica, 3(1):85-96. https://doi.org/10.5327/ S1519-874X2003000100007 
Haddad R.C. 1995. Batólito granitoide Pinhal-Ipuiuna (SP-MG): um exemplo do magnetismo cálcio-alcalino potássico neoproterozoico no sudeste brasileiro. PhD Thesis, Universidade de São Paulo, São Paulo.

Haddad R.C., Janasi V.D.A., Ulbrich H.H.G.J. 1997. Caracterização Geoquímica Preliminar Dos Granitóides Aflorantes Nas Vizinhanças Do Batólito Pinhal-Ipuiúna (Sp-Mg). Revista Brasileira de Geociências, 27(1):129-138

Hammarstrom J.M., Zen E. 1986. Aluminum in hornblende: an empirical igneous geobarometer. American Mineralogist, 71(11-12):1297-1313.

Harlov D.E. \& Hansen E.C. 2005. Oxide and sulphide isograds along a Late Archean, deep-crustal profile in Tamil Nadu, south India. Journal of Metamorphic Geology, 23(4):241-259. https://doi. org/10.1111/j.1525-1314.2005.00574.x

Hawthorne F.C., Oberti R., Harlow G.E., Maresch W. V., Martin R.F. Schumacher J.C., Welch M.D. 2012. Nomenclature of the amphibole supergroup. American Mineralogist, 97(11-12):2031-2048. http:// dx.doi.org/10.2138/am.2012.4276

Henry D.J., Guidotti C.V., Thomson J.A. 2005. The Ti-saturation surface for low-to-medium pressure metapelitic biotites: Implications for geothermometry and Ti-substitution mechanisms. American Mineralogist, 90(2-3):316-328. http://dx.doi.org/10.2138/ am.2005.1498

Holland T. \& Blundy J. 1994. Non-ideal interactions in calcic amphiboles and their bearing on amphibole-plagioclase thermometry. Contributions to Mineralogy and Petrology. 116(4):433-447. https://doi.org/10.1007/BF00310910

Icenhower J.P. \& London D. 1997. Partitioning of fluorine and chlorine between biotite and granitic melt: experimental calibration at $200 \mathrm{MPa}$ H2O. Contributions to Mineralogy and Petrology, 127(12):17-29. https://doi.org/10.1007/s004100050262

Ishihara S. 1977. The magnetite-series and ilmenite-series granitic rocks. Mining Geology, 27(145):293-305. https://doi.org/10.11456/ shigenchishitsu1951.27.293

Janasi V. de A. 1999. Petrogênese de granitos crustais na Nappe de Empurrão Socorro-Guaxupé (SP-MG): uma contribuição da geoquímica elemental e isotópica. Thesis, Universidade de São Paulo, São Paulo, 316 p. http://dx.doi.org/10.11606/T.44.2013. tde-04062013-164954

Janasi V. de A., Martins L., Vlach S.R.F. 2005. Detailed field work in two outcrops of the Nazaré Paulista anatectic granite, SE Brazil. Revista Brasileira de Geociências, 35(1):99-110. http://dx.doi. org/10.25249/0375-7536.200535199110

Janasi V.D.A., Vlach S.R.F., Campos Neto M.D.C., Ulbrich H.H.G.J. 2009. Associated A-type subalkaline and high-K calc-alkaline granites in the Itu Granite Province, southeastern Brazil: Petrological and tectonic significance. Canadian Mineralogist, 47(6):1505-1526. https://doi.org/10.3749/canmin.47.6.1505

Korneliussen A., McEnroe S., Nilsson L.P., Schiellerup H., Gautneb H., Meyer G.B., Størseth L.R. 2000. An overview of titanium deposits in Norway. Norges geologiske undersøkelse Bulletin, 436:27-38

Le Maitre R.W., Streckeisen A., Zanettin B., Le Bas M.J., Bonin B., Bateman P. 2002. Igneous Rocks: A Classification and Glossary of Terms. Cambridge, Cambridge University Press.

Leake B.E., Woolley A.R., Arps C.E.S., Birch W.D., Gilbert C.M., Grice J.D., Hawthorne F.C., Kato A., Kisch H.J., Krivovichev V.G., Linthout K., Laird J., Mandarino J.A., Maresch W.V., Nickel E.H., Rock N.M.S., Schumacher J.C., Smith D.C., Stephenson N.C.N., Ungaretti L., Whittaker E.J.W., Youzhi G. 1997. Nomenclature of Amphiboles: Report of the Subcommittee of the International Commission on New Minerals and Mineral Names. The Canadian Mineralogist, 35:219-246.
Martins L. 2006. Geração e migração de magmas graníticos na crosta continental: estudos de detalhe em granitos e migmatitos da região de Nazaré Paulista (SP). PhD Thesis, Universidade de São Paulo, São Paulo, 240. http://dx.doi.org/10.11606/T.44.2006. tde-19042007-155618

Martins L., Vlach S.R.F., Janasi V. de A. 2009. Reaction microtextures of monazite: Correlation between chemical and age domains in the Nazaré Paulista migmatite, SE Brazil. Chemical Geology, 261(34):271-285. https://doi.org/10.1016/j.chemgeo.2008.09.020

Mason R.A. 1992. Models of order and iron-fluorine avoidance in biotite. Canadian Mineralogist, 30:343-354.

McDonough W.F., Sun S.S. 1995. The composition of the Earth. Chemical Geology, 120(3-4):223-253. https://doi. org/10.1016/0009-2541(94)00140-4

McEnroe S.A., Fabian K., Robinson P., Gaina C., Brown L.L 2009. Crustal magnetism lamellar magnetism and rocks that remember. Elements, 5(4):241-246. https://doi.org/10.2113/ gselements.5.4.241

McGuire A., Francis C., Dyar M. 1992. Mineral standards for electron microprobe analysis of oxygen. American Mineralogist, 77:1087-1091

Mehdilo A., Irannajad M., Rezai B. 2015. Chemical and mineralogical composition of ilmenite: Effects on physical and surface properties. Minerals Engineering, 70:64-76. https://doi. org/10.1016/j.mineng.2014.09.002

Miller C.F., McDowell S.M., Mapes R.W. 2003. Hot and cold granites: Implications of zircon saturation temperatures and preservation of inheritance. Geology, 31(6):529-532. https://doi.org/10.1130/0091-7613(2003)031<0529:HACGI $0>2.0 . \mathrm{CO} ; 2$

Molina J.F., Moreno J.A., Castro A., Rodríguez C., Fershtater G.B 2015. Calcic amphibole thermobarometry in metamorphic and igneous rocks: New calibrations based on plagioclase/ amphibole $\mathrm{Al}-\mathrm{Si}$ partitioning and amphibole/liquid $\mathrm{Mg}$ partitioning. Lithos, 232:286-305. https://doi.org/10.1016/j. lithos.2015.06.027

Mori P.E., Correia C.T., Reeves S., Haukka M. 1999. Development of a fused glass disc XRF facility and comparison with the pressed powder pellet technique at Instituto de Geociencias, Sao Paulo University. Revista Brasileira de Geociências, 29(3):441-446.

Munoz J.L. 1984. F-OH and Cl-OH exchange in micas with applications to hydrothermal ore deposits. Reviews in Mineralogy and Geochemistry, 13(1):469-493.

Munoz J.L. 1992. Calculation of $\mathrm{HF}$ and $\mathrm{HCl}$ fugacities from biotite compositions: revised equations. In: Geological Society of America. Abstract Programs... p. A221.

Mutch E.J.F., Blundy J.D., Tattitch B.C., Cooper F.J., Brooker R.A. 2016. An experimental study of amphibole stability in low-pressure granitic magmas and a revised Al-in-hornblende geobarometer. Contributions to Mineralogy and Petrology, 171(10):1-27. https://doi. org/10.1007/s00410-016-1298-9

Nachit H., Ibhi A., Abia E.H., Ben Ohoud M. 2005. Discrimination between primary magmatic biotites, reequilibrated biotites and neoformed biotites. Comptes Rendus Geoscience, 337(16):14151420. https://doi.org/10.1016/j.crte.2005.09.002

Navarro M.S., Andrade S., Ulbrich H., Gomes C.B., Girardi V.A.V. 2008. The Direct Determination of Rare Earth Elements in Basaltic and Related Rocks using ICP-MS: Testing the Efficiency of Microwave Oven Sample Decomposition Procedures. Geostandards and Geoanalytical Research, 32(2):167-180. https://doi.org/10.1111/j.1751-908X.2008.00840.x 
Noyes H.J., Wones D.R., Frey F.A. 1983. A Tale of Two Plutons: Petrographic and Mineralogic Constraints on the Petrogenesis of the Red Lake and Eagle Peak Plutons, Central Sierra Nevada, California. The Journal of Geology, 91(4):353-379.

Pascholati E.M., Vlach S.R.F., Amaral G. 1987. Contribuição ao conhecimento da Suite Intrusiva Itu, São Paulo. Simpósio Regional de Geologia, 6:47-62.

Pitcher W.S. 1982. Granite type and tectonic environment. Mountain building processes, 19-40.

Richards J.P. 2015. The oxidation state, and sulfur and $\mathrm{Cu}$ contents of arc magmas: implications for metallogeny. Lithos, 233:27-45. https://doi.org/10.1016/j.lithos.2014.12.011

Ridolf F. \& Renzulli A. 2012. Calcic amphiboles in calc-alkaline and alkaline magmas: Thermobarometric and chemometric empirical equations valid up to $1,130^{\circ} \mathrm{C}$ and $2.2 \mathrm{GPa}$. Contributions to Mineralogy and Petrology, 163(5):877-895. https://doi.org/10.1007/ s00410-011-0704-6

Ridolfi F., Renzulli A., Puerini M. 2010. Stability and chemical equilibrium of amphibole in calc-alkaline magmas: An overview, new thermobarometric formulations and application to subduction-related volcanoes. Contributions to Mineralogy and Petrology, 160(1):45-66. https://doi.org/10.1007/ s00410-009-0465-7

Rocha B.C., Moraes R., Möller A., Cioff C.R., Jercinovic M.J. 2017. Timing of anatexis and melt crystallization in the Socorro-Guaxupé Nappe, SE Brazil: Insights from trace element composition of zircon, monazite and garnet coupled to U-Pb geochronology. Lithos, 277:337-355. https://doi.org/10.1016/j.lithos.2016.05.020

Rollinson H.R. 1993. Using geochemical data: evaluation, presentation, interpretation. United States: Routledge.

Salazar Mora C.A., Campos Neto M. da C., Basei M.A.S. 2014. Syncollisional lower continental crust anatexis in the Neoproterozoic Socorro-Guaxupé Nappe System, southern Brasília Orogen, Brazil: Constraints from zircon U-Pb dating, Sr-Nd-Hf signatures and whole-rock geochemistry. Precambrian Research, 255(S2):847-864. http://dx.doi.org/10.1016/j.precamres.2014.10.017

Salazar-Naranjo A.F. 2016. Experimentos de fusão-desidratação (400 $\mathrm{MPa}, 950^{\circ} \mathrm{C}$ ) de granitos cálcio-alcalinos de alto $\mathrm{K}$ (Bragança Paulista, SP) e implicações para a geração de granitos ferroanos peraluminosos. Master's Dissertation, Universidade de São Paulo, São Paulo, 220 p. http://dx.doi.org/10.11606/D.44.2017.tde-30032017-103508

Sauerzapf U., Lattard D., Burchard M., Engelmann R. 2008. The titanomagnetite-ilmenite equilibrium: New experimental data and thermo-oxybarometric application to the crystallization of basic to intermediate rocks. Journal of Petrology, 49(6):1161-1185. https:// doi.org/10.1093/petrology/egn021

Schmidt M.W. 1992. Amphibole composition in tonalite as a function of pressure: an experimental calibration of the Al-in-hornblende barometer. Contributions to Mineralogy and Petrology, 110(2-3):304-310. https://doi.org/10.1007/ BF00310745

Teiber H., Marks M.A.W., Wenzel T., Siebel W., Altherr R., Markl G. 2014. The distribution of halogens $(\mathrm{F}, \mathrm{Cl}, \mathrm{Br})$ in granitoid rocks. Chemical Geology, 374-375:92-109. https://doi.org/10.1016/j. chemgeo.2014.03.006
Töpfner C. 1996. Brasiliano-Granitoide in den Bundesstaaten São Paulo und Minas Gerais, Brasilien: eine vergleichende Studie; Zirkontypologie, U-(Th)-Pb-und Rb-Sr-Altersbestimmungen. München, Inst. für Allg. u. Angewandte Geologie/ Ludwig-Maximilians-Univ.

Trouw R.A.J., Heilbron M., Ribeiro A., Paciullo F., Valeriano C.M., Almeida J.C.H., Tupinambá M., Andreis R.R. 2000. The central segment of the Ribeira Belt. Tectonic Evolution of South America, 31:287-310.

Vinagre R., Trouw R.A.J., Mendes J.C., Teixeira P.D., Peternel R., Matos G. 2014. New evidence of a magmatic arc in the southern Brasília Belt, Brazil: The Serra da Água Limpa batholith (SocorroGuaxupé Nappe). Journal of South American Earth Sciences, 54:120-139. http://dx.doi.org/10.1016/j.jsames.2014.05.002

Vlach S.R.F. 1993. Geologia e petrologia dos granitóides de Morungaba/SP. PhD Thesis, Universidade de São Paulo, São Paulo, 414 p. http://dx.doi.org/10.11606/T.44.1993. tde-15042013-112501

Vlach S.R.F. \& Gualda G.A.R. 2000. Microprobe monazite dating and the ages of some granitic and metamorphic rocks from southeastern Brazil. Revista Brasileira de Geociências, 30(1):214-218.

Vlach S.R.F. \& Ulbrich H.H.G.J. 1994. Fugacidades de espécies voláteis e evolução de magmas graníticos: inferências a partir dos equilíbrios entre fases minerais máficas para o magmatismo Morungaba e ocorrências associadas do Cinturão Itu, Estado de São Paulo. In: Congresso Brasileiro de Geologia, 38., Camboriú. Boletim de Resumos Expandidos... v. 1, p. 145-146.

Vlach S.R.F., Janasi V.D.A., Vasconsellos A.C.B.C. 1990. The Itú Belt: associated calc-alkaline and aluminous A-type late Brasiliano granitoids in the states of São Paulo and Paraná, southern Brazil. In: Congresso Brasileiro de Geologia, 36., Natal. Anais... v. 4, p. 1700-1711.

Vyhnal C.R., McSween H.Y., Speer J.A. 1991. Hornblende chemistry in southern Appalachian granitoids: implications for aluminum hornblende thermobarometry and magmatic epidote stability. American Mineralogist, 76(1-2):176-188.

Watson E.B. \& Harrison T.M. 1983. Zircon saturation revisited: temperature and composition effects in a variety of crustal magma types. Earth and Planetary Science Letters, 64(2):295-304. https:// doi.org/10.1016/0012-821X(83)90211-X

Watson E.B. \& Harrison T.M. 1984. Accessory minerals and the geochemical evolution of crustal magmatic systems: a summary and prospectus of experimental approaches. Physics of the Earth and Planetary Interiors, 35(1-3):19-30. https://doi. org/10.1016/0031-9201(84)90031-1

Wernick E., Hormann P.K., Artur A.C., Eulert H. 1984. Aspectos Petrológicos do Complexo Granítico Socorro (SP/MG): Dados Analíticos e Discussão preliminar. Revista Brasileira de Geociências, 14(1):23-29.

Wones D.R. 1981. Mafic Silicates as Indicators of Intensive Variables in Granitic Magmas. Mining Geology, 31(168):191-212. https://doi. org/10.11456/shigenchishitsu1951.31.191

WonesD.R.1989.Significanceoftheassemblagetitanite+magnetite+quartz in granitic rocks. American Journal of Science, 74(7-8):744-749.

This is an open access article distributed under the terms of the Creative Commons license. 